\title{
Molecular Insight into the Knockdown Resistance (kdr) in the Voltage Gated Sodium Channel (vgsc) Gene of the Main Dengue Vector, Aedes aegypti (Diptera: Culicidae) and the Discovery of Novel Regional Specific Point Mutation A1007G in Malaysia.
}

Mas Azlin M. Akhir

Universiti Sains Malaysia

Mustafa F. F. Wajidi

Universiti Sains Malaysia

Sébastien Lavoué

Universiti Sains Malaysia

Ghows Azzam

Universiti Sains Malaysia

Izhan Shahrin Jaafar

Ministry of Health Malaysia: Kementerian Kesihatan Malaysia

Noor Aslinda Ummi Awang Besar Awang Besar

Ministry of Health Malaysia: Kementerian Kesihatan Malaysia

Intan Haslina Ishak ( $\boldsymbol{\nabla}$ intanishak@usm.my)

Universiti Sains Malaysia https://orcid.org/0000-0002-8916-0451

Research

Keywords: Aedes aegypti, kdr resistance, A1007G, pyrethroid, insecticide resistance, Malaysia

Posted Date: January 28th, 2021

DOI: https://doi.org/10.21203/rs.3.rs-102568/v2

License: (9) This work is licensed under a Creative Commons Attribution 4.0 International License. Read Full License 


\section{Abstract}

Background: Characterization of the insecticide resistance mechanism imparts the society with the information on the evolutionary process involved in the adaptation of Aedes aegypti mosquito to environmental changes. Investigating the phenotypic status of the target mosquitoes, their resistance level as well as elucidating the genotypic profile provides information about the involvement of insecticide resistance mechanism, in terms of portraying the evolution of resistance in the field, to eventually managing vector control programmes. In this current study, we investigated the quantification responses for the phenotypic and genotypic resistance of Ae. aegypti population from different states in Malaysia.

Methods: We tested insecticide susceptibility status of adult Ae. aegypti from populations of States of Penang, Selangor and Kelantan (Peninsular Malaysia) against $0.25 \%$ permethrin and $0.25 \%$ pirimiphosmethyl through WHO bioassay kit. Permethrin-resistant and permethrin susceptible samples were then genotyped for domains II and III in the voltage gated sodium channel ( $\mathrm{ggsc}$ ) gene using allele specific PCR (AS-PCR) for the presence of diagnostic single nucleotide mutations. AS-PCR results were then validated in sequencing these two domains to identify any possible additional point mutations.

Results: Adult WHO bioassay revealed that populations of Ae. aegypti from these three states were highly resistant towards $0.25 \%$ permethrin and $0.25 \%$ pirimiphos-methyl. Genotyping results showed that three knockdown ( $k d r$ ) mutations (i.e. S989P, V1016G and F1534C) were associated with pyrethroid resistance in these populations. We also report for the first time the presence of the A1007G mutation in Malaysian populations of Ae. aegypti.

Conclusions: This study brings an insight on the occurrence and association of point mutations with insecticide resistance in Malaysian populations of Ae. aegypti. The results reveal the widespread of several $k d r$ mutations in the field with the consequence to compromise the use of pyrethroid insecticides in vector control programmes. Knowledge on the distribution of target site resistance throughout Malaysia is vital to ensure the success of the insecticide-based vector control programme.

\section{Background}

The mosquito Aedes aegypti is a primary vector for some arboviral diseases such as chikungunya [1], dengue [2], Zika [3, 4] and yellow fever [5] which have gained attention worldwide due to their fast spreading trend $[6,7,8,9,10]$. This species is notoriously recognized in transmitting dengue fever and dengue haemorrhagic fever especially in tropical and sub-tropical countries due to their successful adaptation from feeding on animals in natural forest ecosystems to preferentially feeding on humans in anthropogenic modified habitats [11, 12]. In Malaysia, dengue has become a major threat to public health with 93,344 cumulative dengue cases and 137 deaths reported in 2019 , an increase of $81.8 \%$ and $69.1 \%$ respectively from the previous year $[13,14,15]$. Although tetravalent dengue vaccine has recently been 
introduced and portrays good efficacy profile during clinical trial, there are still some restrictions which need to be solved before commercialized in large scale [16].

Various approaches have been conducted to control populations size and distribution of Ae. aegypti, most of them rely on the insecticide-based intervention targeting the immature and adult stages of this species [17]. In Malaysia, pyrethroid and organophosphate are routinely used during the vector control programmes conducted by the Ministry of Health, and also by the private pest control operators and the local communities $[18,19]$. Such excessive use of these insecticide classes for a long period, led to over dependence and improper usage of these insecticides to control the mosquitoes, eventually causing resistance in this vector.

Inappropriate usage and over-exposure to insecticides that share the same mode of action can lead to the selection of several types of insecticide resistance in the mosquitoes: 1 ) the modification of the mosquito cuticle, leading to reduced penetration of the insecticide into the insect's exoskeleton, 2) the presence of the single nucleotide polymorphism (SNP) resulting in the modification of nucleotide in the target gene and consequently changing the amino acid of the target sites in mosquito, 3) increasing in the enzymatic activity in detoxifying the insecticides; or 4) changes in the mosquito behaviour enabling them to survive in the toxic environment [20].

The two resistance mechanisms that are commonly associated with pyrethroid resistance within insects are 1) increased metabolic detoxification activity [21] and 2) the insensitivity of the target site such as sodium channel gene, Ace-1 gene and GABA receptor [22]. Although, organophosphate and pyrethroid have different modes of action, both insecticides target the nervous system of the insect which eventually leads to its death [23]. Several point mutations have been functionally identified in the vgsc gene to reduce its sensitivity by preventing the binding of the insecticide to the target gene, making the insect experience rapid nerve firing and paralysis and consequently leading to the knockdown resistance $(k d r)$ $[24,25,26,27]$.

In Malaysia, three common knockdown ( $k d r)$ mutations within Ae. aegypti voltage gated sodium channel gene (vgsc) are known to be associated with pyrethroid resistance. The non-synonymous mutations S989P, V1016G and F1534C correspond to a substitution of amino acid serine to proline, valine to glycine and phenylalanine to cysteine, respectively, within domains II and III. These mutations were previously shown to be widely distributed across Malaysia [28, 29,30]. Other studies have reported that these mutations are widely established across Southeast Asia, including Indonesia, Thailand, Singapore, Myanmar and Vietnam [31, 32, 33, 34, 35]. Currently, a total of 13 non-synonymous mutations have been detected in the $v g s c$ gene of pyrethroid-resistant Ae. aegypti population worldwide; five of them (V410L, S989P, I1011M, V1016G and F1534C) have been in vitro functionally characterized in the expression system of Xenopus oocytes and reported to confer kdr resistance in Ae. aegypti [24, 25, 26, 27, 36, 37, 38, $39,40]$. Kdrmutations G923V, L982W, I1011M and V1016G were first identified in 2003 which were detected in pyrethroid/DDT resistant Ae. aegypti populations [24]. In 2007, I1011V and V1016I mutations were reported in the Ae. aegypti population from Latin America [25]. Subsequently, D1763Y mutation was 
observed in the pyrethroid resistant population of Ae. aegypti from Taiwan in 2009 [36]. S989P and F1534C mutations were first reported in Ae. aegypti population from Thailand in the following year [37, 41]. In 2015, T1520I mutation was reported in Ae. aegypti population from India [39]. The first $k d r$ mutation in domain I, V410L was first observed in the Brazilian population of Ae. aegypti in 2017 [27]. A1007G mutation was first detected in Ae. aegypti from Vietnam in the following year [42]. Recently, F1534L mutation was reported in the pyrethroid resistant Indian Ae. aegypti populations [43].

Characterizing target site resistance mechanism is an essential key to improve the management strategies of the vector control. Hence, the aim of this study is to further elucidate the insecticide resistance mechanism associated within Malaysian Ae. aegypti population phenotypically and genotypically.

\section{Methods}

Sampling and rearing of mosquitoes

Six populations of Aedes aegypti were collected from three states in Malaysia; Penang, Selangor and Kelantan in 2017 by placing the 100 ovitraps at residential areas for five days. The sites were selected based on the number of reported dengue cases in idengue website (https://idengue.mysa.gov.my/) which is the Malaysian national dengue database (Ministry of Health) and were routinely sprayed with insecticides particularly permethrin and pirimiphos-methyl. We selected two sites within each state (total = six sites): Sungai Dua (SD) and Balik Pulau (BP) in Penang, Alam Budiman (AB) and TUDM, Subang (TDM) in Selangor, and Pauh, Panji (PNJ) and Flat Buluh Kubu (FLT) in Kelantan. A maximum of 100 ovitraps were set up for each of the study site at a distance between 5 to 10 meters apart depending on the type of houses in the residential area. The ovitraps were randomly placed at the potential breeding sources and less exposed to direct sunlight. The traps were collected after five days and brought back to the insectary for culturing purposes.

The eggs of Aedes mosquitoes from all the localities were hatched and upon emergence of first instar larvae, they were fed with the larval food containing grounded cat biscuit, beef liver powder, milk powder and yeast with a ratio of 2:1:1:1. The adult mosquitoes were morphologically identified to the species level based on the pattern on the thorax. The adult Ae. aegypti were supplied with $10 \%$ sucrose solution. All larvae and adults were maintained at room temperature of 282 with a relative humidity of $7510 \%$. The local susceptible laboratory strain obtained from the Vector Control Research Unit (VCRU) which has never been exposed to any insecticides was used as a reference strain.

\section{WHO adult bioassay}

The adult mosquito bioassay was performed according to the World Health Organization (WHO) protocol [44]. Twenty female mosquitoes of Ae. aegypti of three to five days old were tested against $0.25 \%$ permethrin (Type I pyrethroid) and $0.25 \%$ pirimiphos-methyl (organophosphate) for one hour and replicated five times.. The susceptibility bioassay test was conducted in room temperature of 282 with a 
relative humidity of $7510 \%$. Subsequently, they were supplied with $10 \%$ sucrose solution ad libitum and maintained under insectary conditions. The number of dead and alive mosquitoes were recorded at 24 hours post exposure. After 24 hours exposure, the whole bodies of the surviving mosquitoes were transferred and kept in -80 and those of the dead samples were preserved in silica gel inside microcentrifuge tubes for $k d r$ genotyping.

\section{Synergist bioassay}

The synergism assay was conducted as a first screening to investigate the potential role of superfamily enzyme mixed function oxidases and esterase in the insecticide metabolic detoxification. Piperonyl butoxide (PBO) was used before the exposure to permethrin insecticide because it is known as a common synergist for pyrethroid [45] and inhibit enzyme from the family of esterases and mixed function oxidases which are mainly associated with metabolic resistance caused by pyrethroid, organophosphate and carbamate exposure. The test was performed on the individuals from all sampling sites because the percentage mortality was less than $90 \%$ mortality from the previous WHO bioassay test. Adult female mosquitoes were exposed to $4 \%$ PBO one hour before the exposure to $0.25 \%$ permethrin. The mortality of the individual mosquitoes was recorded after 24 hours. To compare the results obtained between the two treatments, we either use only the insecticide or a combination of synergist and insecticide.

Genotyping of $k d r$ mutations in voltage gated sodium channel ( $v g s c)$ gene in Aedes aegypti

\section{Extraction of genomic DNA (gDNA)}

The gDNA of 20 dead and alive samples from all localities were extracted from legs and wings following Livak protocol [46]. The body of survived mosquitoes were kept in -80 for the quantification of metabolic resistance by real-time PCR. The DNA concentration and purity were measured using a Nanodrop spectrophotometer at $260 \mathrm{~nm}$. The gDNA samples were stored in the -20 for the downstream application.

\section{Detection of the V1016G mutation by using allele specific PCR (AS-PCR) in Aedes aegypti}

To determine the presence of $\mathrm{V} 1016 \mathrm{G}$ and $\mathrm{F} 1534 \mathrm{C}$ point mutations conferring pyrethroid resistance, 20 female mosquitoes from each resistant and susceptible field population were randomly chosen for this genotyping using AS-PCR. From a total of 100 female mosquitoes, 20 resistant individuals and 20 susceptible individuals were genotyped using AS-PCR protocol as previously described by Stenhouse et al. [32]. V1016G mutation was genotyped in 20 resistant and susceptible individuals that were exposed to permethrin previously. Each reaction used consisted of a total volume of $15 \mathrm{I}$ of $1.25 \mathrm{mM} \mathrm{MgCl}_{2}, 1 \mathrm{PCR}$ buffer (Thermo Scientific, USA), 0.3 M forward primer (Gly1016f), 0.2M for each reverse primer (Gly1016r or Val1016r), 200M dNTP mixture (Promega, USA), 1.25 units DreamTaq Hot Start DNA polymerase (Thermo Scientific, USA) and 25-100 ng of gDNA. The amplification was carried out using Bio-rad MyCycler ${ }^{\mathrm{TM}}$ Thermal Cycle (Hercules, California, USA). The thermal cycling condition was: 94 for 2 min (initial denaturation); 35 cycles of 94 for $30 \mathrm{sec}$ (denaturation), 58 for $30 \mathrm{sec}$ (annealing), 72 for $30 \mathrm{sec}$ 
(extension) and 72 for 2 min (final extension). The PCR products were loaded checked onto $3 \%$ agarose gel. The sizes of the two amplified fragments are 60 base pairs [bp] for valine and $80 \mathrm{bp}$ for glycine.

\section{Genotyping of F1534C by using allele specific (AS-PCR) in Aedes aegypti}

For the amplification of F1534C in domain III segment 6 (DIII S6), this kdrmutation was genotyped by ASPCR as described by Yanola et al. [41]. The PCR reaction was performed in final volume of $15 \mathrm{I}$ with a final concentration of $0.5 \mathrm{mM} \mathrm{MgCl}_{2}, 1.5 \mathrm{PCR}$ buffer (Thermo Scientific, USA), $0.3 \mathrm{M}$ for each forward primer (F1534-f and C1534-f), 0.23 M reverse primer (CP-r), 0.2mM dNTP mixture (Promega, USA), 1.25 units DreamTaq Hot Start DNA polymerase (Thermo Scientific, USA) and 25-100 ng of gDNA. The reaction was run at 95 for $2 \mathrm{~min}$ (initial denaturation); 35 cycles of 95 for $30 \mathrm{sec}$ (denaturation), 56 for $30 \mathrm{sec}$ (annealing), 72 for $45 \mathrm{sec}$ (extension) and 72 for $2 \mathrm{~min}$ (final extension). The products were run in $3 \%$ agarose gel.

\section{Validating polymorphism sites of the voltage gated sodium channel (vgsc) gene in Aedes aegypti by DNA sequencing}

Some of the AS-PCR products were sequenced in order to verify the accuracy of results obtained from the AS-PCR assay and, also, to detect any possible novel mutation. The regions of DIIS6 and DIIIS6 in the vgsc gene (where the V1016G and F1534C mutations occur) were separately amplified (by PCR) using the protocol described in Stenhouse et al. [32] and Yanola et al. [41]. Each reaction was performed in $20 \mathrm{I}$ final volume consisting of $1.5 \mathrm{mM} \mathrm{MgCl}_{2}, 0.2 \mathrm{M}$ each for forward and reverse primers for each fragment, $0.4 \mathrm{mM}$ dNTP, 1 PCR buffer and 1.0 units of GoTaq G2 Flexi DNA Polymerase (Promega, USA). PCR amplification began with $3 \mathrm{~min}$ at 95 (heat activation step), 35 cycles of 95 for $30 \mathrm{sec}$ (denaturation), 57 for $30 \mathrm{sec}$ (annealing), 72 for $30 \mathrm{sec}$ (extension) and 72 for $3 \mathrm{~min}$ (final extension). PCR products were sent to Integrated DNA Technologies, Inc. for sequencing.

Chromatograms were first edited using MEGA 6 Molecular Evolutionary Genetic Analysis software, version 6.06 [47]. The sequences determined in this study have been deposited in GenBank (GenBank accession nos. MT237357-MT237435). Then, all nucleotide sequences of the haplotype for domains II and III were aligned (no indels needed). Our phylogenetic matrix comprises 46 individuals and 491 and 346 nucleotide positions for domain II and domain III respectively. We inferred the relationships among the individuals using a maximum parsimony method of phylogenetic reconstruction as implemented in PAUP* v4b10 [48]. Susceptible Musca domestica (GenBank accession number U38813.1) was selected as the outgroup to root the tree. The haplotype TCS network was built using the PopART $[49,50]$ software to determine the correspondence/relation between haplotype and the resistance/susceptible phenotypes.

\section{Statistical analysis}

Percentage mortality at 24 hours post exposure for each of the population was used to describe the phenotype status. The classification of the susceptible and resistant phenotype in the tested populations were interpreted according to the WHO guidelines [44]. The tested population was considered to be 
susceptible if the percentage mortality ranged from $98 \%$ to $100 \%$; mortality ranged from $90 \%$ to $97 \%$ suggests that the population has developed intermediate resistance; and the population was considered to be resistant if the percentage mortality less than $90 \%$. Odds ratio (OR) and Fisher's exact test were conducted to compare the distribution of $k d r$ genotypes between the alive and dead mosquitoes. Chisquare analysis was used to test the significant differences in percentage mortality with and without preexposure to PBO. All statistical analysis was performed using The Statistical Package for Social Science software (IBM SPSS Statistics version 24).

\section{Results}

\section{WHO adult bioassay}

The diagnostic dosage for Aedes mosquito was used for permethrin and the tentative dosage for Anopheles was used for pirimiphos-methyl. WHO bioassays on the field strains revealed phenotypic resistance in populations from Selangor, Penang and Kelantan with percentage mortality less than $90 \%$ after exposure towards permethrin and pirimiphos-methyl (Fig. 1). Aedes aegypti from all six populations were highly resistant towards both insecticides with percentage mortality, after 24 hours exposure, varying from $0 \%$ to only $18 \%$ and $3 \%$ to $58 \%$ for $0.25 \%$ permethrin and $0.25 \%$ pirimiphos-methyl, respectively. Full susceptibility was observed in Ae. aegypti from the VCRU laboratory strain, after the exposure towards both insecticides (Fig. 1).

High resistance towards permethrin was observed in all six populations. The lowest percentage of mortality was observed in the populations from Pauh, Panji (PNJ) and Flat Buluh Kubu (FLT), Kelantan with $0 \%$ and $1 \%$ mortality, respectively, indicating that these two populations developed very strong resistance and the need of additional assessment regarding the genetic mechanisms and distribution of such resistance. Aedes aegypti from TUDM, Subang (TDM) shows the highest mortality compared to other populations with $18 \%$, although such percentage of mortality is still quite low. Widespread resistant towards $0.25 \%$ pirimiphos-methyl was also observed in all populations with the highest resistance level recorded in Alam Budiman, Selangor (AB) with 3\% mortality. Meanwhile, the population from Balik Pulau, Penang (BP) exhibited the highest mortality against pirimiphos-methyl with $58 \%$ mortality.

\section{Synergism assay with piperonyl butoxide (PBO)}

Percentage mortality of all populations except Pauh, Panji, (PNJ) after subjected to one-hour preexposure to $4 \%$ PBO before being exposed to permethrin, displays an increase in the mortality ranging from $2 \%$ to $69 \%$ (Fig. 1). Pre-exposure to synergist showed an increase in mortality for populations from TUDM, Subang (TDM) and Balik Pulau (BP) with percentage mortality of $29 \%$ and $69 \%$ respectively after being exposed to permethrinThese two populations showed a major increase of percentage mortality compared to the other populations, in addition, Ae. aegypti from Balik Pulau (BP) showed a significant increase in susceptibility towards permethrin $\left(X^{2}=7.244, \mathrm{df}=1, P=0.007\right)$. No impact of pre-exposure to 
synergist PBO was observed in the population from Pauh, Panji (Kelantan) with $0 \%$ mortality before and after exposure to synergist.

Detection of $k d r$ mutation in the $v g s c$ gene of Malaysian population Aedes aegypti

167 samples including dead and alive mosquitoes from all populations were genotyped in order to determine the presence of S989P, V1016G and F1534C in DII and DIII and the allelic frequencies. Results of the genotyping are shown in Tables 1 (S989P), 2 (V1016G) and 3 (F1534C).

To detect other possible point mutations in the $v g s c$ gene of the Malaysian population Ae. aegypti, the partial $v g s c$ gene was sequenced. The length of the first fragment is $491 \mathrm{bp}$, spanning codons 989, 1011 and 1016; the same synonymous mutation was detected at the nucleotide positions 33 and 132: A to G. Sequence comparison with the pyrethroid susceptible Musca domestica (GenBank accession number U38813.1) and Ae. aegypti China strain (GenBank accession number MF794972.1) revealed six nucleotide substitutions, four of them non-synonymous resulting in four amino acid changes in the domains II and III of the $v g s c$ gene in the permethrin resistant and susceptible samples from the six populations in Malaysia.

Several non-synonymous mutations in domain II, have been detected at codon 989 and 1016. Samples from Sungai Dua (SD), Balik Pulau (BP), Alam Budiman (AB) and TUDM, Subang (TDM) were heterozygous and homozygous for a double amino acid change. This amino acid change occurs at codon position 989, a change of wildtype amino acid serine (TCC) to proline (CCC), due to T/C substitution at nucleotide position 52 . This mutation was specifically detected in populations from Penang, Selangor and in one sample from Flat Buluh Kubu, Kelantan (FLT) with the allelic frequency ranging from 0.1 to 1.0 (Table 1 ).

At codon 1016, a polymorphism was detected in populations from Penang and Selangor (but not in those of Kelantan). A mutation from valine to glycine at codon position 1016 was identified within these populations. A mutation of wildtype GTA to mutant allele GGA was detected from those populations with allelic frequency ranging from $5 \%$ to $55 \%$ (Table 2). Among 167 samples genotyped, a total of 46 samples were partially sequenced in domain II to valid the results obtained from AS-PCR for point mutation V1016G. Eighteen samples showed discrepancy where heterozygous allele (V/G) (from AS-PCR) turned out to be homozygous wild type allele $(\mathrm{V} / \mathrm{V})$ after Sanger sequencing. This might be due to the presence of two consecutive alternative mutations in domain II segment 6 leading to genotyping error, hence resulting in the false positive results [28]. In addition, the amplification of the non-specific band happens due to the mismatch of the single base in the gene, hence it is unable to prevent the non-specific amplification during the PCR extension [51].

A novel non-synonymous substitution has been discovered at codon position 1007, a mutation from alanine (GCC) to glycine (GGC), happens due to changes of nucleotide $C$ to $G$ at position 1007 in the sequence. Our results show that only permethrin resistant samples from Pauh, Panji (PNJ) and Flat Buluh Kubu (FLT) have this novel amino acid substitution, with the percentage of $1007 \mathrm{G}$ allele were $85 \%$ and 
$90 \%$, respectively. Interestingly, the populations that possess this mutation will not co-occur with other point mutations either S989P or V1016G in domain II and could only be found in samples from Kelantan state. Our results indicate this point mutation alone in domain II might be responsible in conferring the high resistance in the phenotypes since there is no other point mutation in domain II that coexist after genotyping using direct sequencing (Fig. 2). Result from the direct sequencing reveals populations from Kelantan that possess this novel mutation will coexist with another point mutation in domain III which is the F1534C mutation (Fig. 2, Fig. 3). All samples from these localities were a mixture of heterozygous and homozygous for the double substitution mutations. These populations were either heterozygous or homozygous mutant to codon 1007 and shares another amino acid change at codon 1534 and are homozygous mutant at this position (Additional file: Table S3). This might explain why the population from Kelantan were highly resistant towards permethrin.

In domain III, a change from phenylalanine (TTC) to cysteine (TTG) at codon 1534 was detected in all six populations with allelic frequency ranging from 0.028 to 0.975 and populations from Kelantan showing the highest allele frequency for the permethrin-resistant samples; more than $90 \%$. We also recorded that the mutant allele, $1534 \mathrm{C}$ are common in the susceptible samples from Penang and TUDM, Subang (TDM) (Table 3, Additional file: Fig. S1).

\section{Association between $k d r$ mutation at domain II and III with pyrethroid resistance}

To assess the correlation with the resistance phenotype, a total of 167 resistant and susceptible mosquitoes from all populations were then genotyped at domains II and III. To ascertain the impact of $k d r$ mutations at different codons; 989, 1007, 1016 and 1534 of the $v g s c$ gene towards pyrethroid resistance, the S989P, A1007G, V1016G and F1534C mutations were analysed separately for their associations with the permethrin resistance.

The S989P mutation in domain II is not significantly associated with the pyrethroid resistance in all populations (Fisher's exact test, $P=0.146$ ) and we presume the populations were not at Hardy-Weinberg equilibrium due to low samples size tested for genotyping at codon 989 (Table 1). Fisher's exact test was conducted to compare the differences in $1016 \mathrm{G}$ of the allelic frequency between the resistant and susceptible phenotype from each locality. At codon 1016, population from TUDM, Subang (TDM) was significantly associated with the permethrin resistance [Odds Ratio (OR): $3.696, p<0.05$ ] and population from Sungai Dua, Penang (SD) was slightly correlated with the permethrin resistance [OR: $0.29, p<0.05]$ (Table 2). In most of the localities, the differences in the allelic frequencies between alive and dead mosquitoes were not significantly correlated $(P=0.429)$. More heterozygote mosquitoes survived after the exposure towards permethrin (Additional file: Fig. S1).

We cannot determine the correlation between novel mutation, $A 1007 \mathrm{G}$ with the permethrin resistance in population from Kelantan due to the low number of susceptible samples obtained after WHO bioassay. Despite that, we found an extremely high $1007 \mathrm{G}$ allele frequency ranging from $85 \%$ to $90 \%$ (Table 4 ). This probably explained why the mortality of the population from Kelantan were exceptionally low (Table 4). 
The frequency of the $1534 \mathrm{C}$ allele in domain III was significantly different between alive and dead mosquitoes from all six populations $\left(X^{2}=51.26, \mathrm{df}=1, \mathrm{p}<0.001\right)$. The $1534 \mathrm{C}$ mutant allele was highly significant associated in the population from Balik Pulau (BP) and TUDM, Subang (TDM) [Odds Ratio (OR): $3.318, p<0.05$ and OR: 16.852, $p<0.05$ ] (Table 3). There is no significant correlation observed between $1534 \mathrm{C}$ genotype and permethrin resistance in Sungai Dua (SD) [OR: 1.069, $p>0.05$ ]. From the Fisher's exacts test, we found that Alam Budiman (AB), Pauh, Panji (PNJ) and Flat Bulu Kubu (FLT) were not in the Hardy-Weinberg equilibrium $(p>0.05)$ and we speculate that this might be due to the deficit of the heterozygote allele.

\section{Distribution of triple-loci and quadruple-loci of the genotypic combination in the domain II and III of the vgsc gene in Ae. aegypti}

In a total of 46 samples genotyped in domain II and III, we found 13 different combination patterns of substitutions in Malaysian populations of Ae. aegypti with nine types of triple-locus and four type of quadruple-locus combination observed within those populations. The combination of the triple-locus genotype detected in each population (Selangor and Penang) ranging from one single type to four different types. Meanwhile, two to three types of combination for quadruple-locus genotyped was observed in the population from Kelantan (Additional file: Table S2). Triple-locus wild type homozygote, S989+V1016+F1534 (Type 1) and quadruple-locus wild type homozygote, S989+A1007+V1016+F1534 (Type 10) was found in four susceptible samples from Selangor and one susceptible sample from Kelantan respectively. Most of the locus genotyped were a combination of two to three amino acid substitution. We noticed triple-loci $k d r$ genotypes (Type 3,4,5,6) resulted in the phenotypic resistant in the samples from Selangor and Penang. The presence of single mutation, S989+1016G+F1534 (Type 2) were seen in the population from Selangor only. Interestingly, the combination of the triple mutant, $989 P+1016 G+1534 C$ happens to be present in one susceptible sample from Penang. This individual which possesses this genotype combination survived after 24 hours exposure period, suggesting the heterozygous allele at codon 1534 might confer lack resistance phenotypically in this sample. Four combination of quadruple-locus genotype was particularly present in population from Kelantan only with three combinations of locus; 989P+A1007+1016G+F1534; S989+1007G+V1016+1534C;

S989+1007A/G+1534C (Type 11, 12 and 13) were detected in permethrin-resistant samples and one locus, S989+A1007+V1016+F1534 (Type 10) found only in permethrin-susceptible sample. Those loci consist of the new mutation with a high number resulting in 15 individuals (Kelantan population) surviving after the exposure of the permethrin.

\section{Haplotype distribution and polymorphism analysis of the $v g s c$ gene fragment in Malaysian population of Ae. aegypti}

Seven haplotypes were identified with five haplotypes present in domain II and two haplotypes was observed in domain III. These haplotype variations produced four amino acid substitution. In the coding region of domain II, we found five polymorphic sites resulting in three non-synonymous changes (S989P, A1007G and V1016G mutations) and two synonymous changes. Meanwhile in the coding region of 
domain III, one polymorphic site at codon 1534 could be observed leading to the two haplotypes created in this vgsc fragment. In general, the $v g s c$ gene exhibits low polymorphism level for all six populations in Malaysia with a low number of the mutational steps between the haplotypes in domain II and III as shown in the TCS network (Fig. 4). From the TCS network analysis in domain II, four resistant haplotypes were observed with one singleton haplotype $4(\mathrm{H} 4)$ and haplotype $5(\mathrm{H} 5)$ which is a combination of the new mutation and synonymous change were detected in Kelantan samples only.

There are five different haplotypes with two major haplotype that are established from all six Ae. aegypti populations in Malaysia (Fig. 4A). Interestingly, in haplotype 4 (H4) and haplotype 5 (H5), we found a novel regional mutation in domain II segment 6 which comprised of resistant samples from Kelantan state only and consisted of both homozygous and heterozygous A1007G mutation. These samples from Pauh, Panji and Flat Bulu Kubu were homozygous susceptible for S989P and V1016G mutations.

There are only two haplotypes that were found to be associated with the F1534C mutation in domain III of the vgsc gene. In domain III, haplotype 1 (H1) was associated with F1534C mutation revealing that all resistant samples from six populations were homozygous resistant for F1534C mutation (Fig. 4B). Haplotype $2(\mathrm{H} 2)$ has homozygous susceptible allele, F1534.

There is no significant difference in the Tajima's D estimation in the $v g s c$ fragment for both domain II and III demonstrating a low number of the polymorphisms in the $v g s c$ within those populations (Table 5). The presence of the predominant haplotypes in both domain II and III gave us an idea that there is selection pressure in the $v g s c$ gene fragment in both domain II and III which is in agreement with the existence of the $k d r$ mutation in this Malaysian population of Ae. aegypti. Maximum parsimony phylogenetic tree analysis of the $v g s c$ gene display an association between the pyrethroid resistance and the single nucleotide polymorphism of domain II and III in the $v g s c$ gene respectively (Additional file: Fig. S2A, Fig. $\mathrm{S} 2 \mathrm{~B})$. The existence of polymorphism in exon 15 to 16 domain II and exon 23 to 25 of domain III of $\mathrm{vgsC}$ gene potentially correlated with the permethrin resistance. Reconstruction of the maximum parsimony tree revealed the haplotype pattern within those domains clustered according to the phenotype of the mosquito samples.

\section{Discussion}

The development of insecticide resistance worldwide has become worrisome problem since a few decades ago [10]. Malaysia is one of the countries that is confronted with this scenario [52]. The present study reveals that the susceptibility status and the distribution of the $k d r$ allele in the Malaysian main dengue vector, Aedes aegypti in Malaysia. This study focuses on the significant role of target site mutation in conferring pyrethroid resistance in this species.

\section{Resistance profiles of Aedes aegypti}

Currently, pyrethroid and organophosphate are the major classes of insecticides that are widely used to eliminate the Aedes mosquitoes during the dengue outbreak and these classes of insecticides have been 
routinely switched by the Ministry of Health Malaysia throughout the control programmes. In addition, the pest control industry also has been using the same classes of insecticides for the same purpose. This action has probably resulted in the selection pressure within the natural populations due to the high exposure towards the insecticides during the control measures and hence have the ability in adapting to the changes of the harsh environment [53]. High occurrence of permethrin resistance in Ae. aegypti is frequently reported in many countries from Southeast Asia including Singapore, Indonesia, Cambodia, Laos, Thailand, Myanmar and Vietnam [31, 34, 35, 54, 55, 56, 57, 58, 59]. The increasing occurrence of the pyrethroid resistance is alarming to governments and private sectors involved in vector management.

The overall low percentage mortality observed in all six populations against $0.25 \%$ permethrin and $0.25 \%$ pirimiphos-methyl indicated that they showed high resistance towards these insecticides and suggests these insecticides might not be effective for the control of these mosquito populations. Resistance ratio (RR) cannot be determined in this study because there were no knocked down mosquitoes during the onehour exposure towards permethrin and pirimiphos-methyl and this probably reflects that the populations are highly resistant towards both insecticides. Results of the susceptibility bioassay revealed that $A e$. aegypti populations from Penang, Kelantan and Selangor exhibit high resistance towards the insecticides from the class of pyrethroid (Type l: permethrin) and organophosphate (pirimiphos-methyl) with the percentage mortality after 24 -hour exposure less than $90 \%$ confirming these populations are resistant as shown in previous studies recently $[28,29,30]$. However, our results contradicted a study conducted in 2011 revealing that $A$ e. aegypti populations from Penang were at that time fully susceptible towards pirimiphos-methyl and malathion [60]. One explanation could be that the Penang populations recently developed resistance against these insecticides compromising the application of this insecticide during vector control programmes. Phenotypic pyrethroid resistance is still increasing in Malaysian population of Ae. aegypti as a consequence of the wide usage of pyrethroid for decades. To understand the genetic basis of resistance mechanisms and their distribution in Malaysia, those populations were subjected to additional investigation.

In Malaysia, dengue vector control programme highly relies on the use of chemical insecticides [61]. Application of chemical insecticides during thermal fogging and space spray to control adult Ae. aegypti has been conducted for more than a decade [18]. Generally, pyrethroid and organophosphate insecticides have been widely used for the insecticidal treatment against the primary vector for dengue, Ae. aegypti. To date, permethrin and pirimiphos-methyl have been used simultaneously to control adult Ae. aegypti during the vector control programme by the public health authorities [62]. Previously, in the early 1970, malathion was first used in fogging to control against adult mosquito vectors. However, its usage discontinued and was replaced by permethrin and deltamethrin in 1998 [52]. These type I and type II pyrethroids have continued to be used until today. Not only that, pyrethroid is also used in the household insecticide products such as liquid vaporizer, aerosol, mosquito coils and mosquito mats [61]. These products have formulations containing active ingredients of metofluthrin, tetramethrin, d-allethrin, transfluthrin, d-phenothrin, s-bioallethrin, cyphenothrin, deltamethrin, d-trans allethrin, prallethrin and permethrin $[61,62,63]$. The extensive usage of household insecticide products may exert selection 
pressure in the target mosquito population and thus might cause cross-resistance in these pyrethroid insecticides.

Apart from controlling adult Ae. aegypti, targeting at the larval stage using larvicidal treatment such as temephos also has been conducted as a part of vector control. Temephos has been widely used to control mosquito larvae since 1973. As a consequence, effective long term usage of temephos has been compromised due to the development of resistance towards this particular insecticide $[28,64]$. Therefore, surveillance on the phenotypic status of Malaysian Ae. aegypti across all the other states in Malaysia as well as their genotypic frequencies between the $k d r$ alleles is crucial in the vector control programme and should be monitored over the time. This could provide conclusive evidence in deciding which vector control strategies should be implemented to improve the management of the control programme.

Development of resistance towards pyrethroid insecticide in Malaysia is notably observed since the year 2001 and it is gradually increasing yearly [52]. Although the authorities practice insecticide rotation, the use of insecticides from the same class and having the same mode of action causes the resistance problem to not be solved. In addition, metabolic cross-resistance could possibly occur between pyrethroid and organophosphate insecticides as a results of insecticide rotation [65]. In particular, insecticide rotation for permethrin and pirimiphos-methyl have been adopted during the control programme as one of the strategies in the insecticide resistance management (IRM) in Malaysia. Hence, further investigation is needed to confirm the involvement of metabolic cross-resistance in Malaysian population of $A e$. aegypti. It is important to note that we did not carry out intensity assay in addition to the 2 diagnostic dose which was recommended in WHO guideline [66] due to insufficient mosquito samples. Future studies such as dose-response study and intensity bioassay should be conducted in local populations to determine the strength of the resistance level among these populations, thus can assist in managing insecticide resistance.

Resistance is usually the combination of two or more mechanisms. Pyrethroid resistance in Ae aegypti is often associated with target site resistance and metabolic resistance [21, 22]. A few studies conducted in Malaysia reveal that several non-synonymous mutations (S989P, V1016G and F1534C) are present in the $k d r$ gene of Ae. aegypti and none of them were reported to occur in Ae. albopictus. First report on the occurrence of the point mutation in the kdrgene in Malaysian population of Ae. aegypti was detected in 2010 whereby the authors found mutation V1016G and F1534C associated with the pyrethroid resistance in Ae. aegypti populations from Penang, Kuala Lumpur, Kota Bharu and Johor Bharu [28]. In year 2018, Rasli et al. [29] have reported the co-occurrence of point mutation, S989P alongside with the reported mutation V1016G in the permethrin-resistant field strains from Kedah and Johor. Subsequently, Leong et al. [30] found the presence of those mutations in the populations from Selangor associated with pyrethroid and DDT resistance. Our present study is in line with the reported point mutations which is associated with pyrethroid resistance in the Malaysian population of Ae. aegypti.

In addition, we unexpectedly discovered a potential novel substitution mutation, A1007G from Kelantan population, which occurs as a single mutation in domain II without the association of other mutations, 
S989P and V1016G, but co-occur with the point mutation in domain III, F1534C. We observed a significant correlation between $\mathrm{V} 1016 \mathrm{G}$ and $\mathrm{F} 1534 \mathrm{C}$ genotypes with the pyrethroid resistance in several localities within these states in Malaysia which shows that those genotypes could possibly attribute towards the pyrethroid type II resistance. In addition, high frequency of the kdrmutations; S989P, A1007G, V1016G and F1534C was detected amongst the six populations in Malaysia, demonstrating target site resistance is partially associated with the resistance towards permethrin. The widespread of these point mutations of S989P, V1016G and F1534C in the kdr gene of the Malaysian population Ae. aegypti might explain the large-scale usage of the insecticide from the class of pyrethroid which had been extensively used by the government and the private sector to control the population of mosquito vectors and especially Aedes species in Malaysia.

\section{A novel mutation in Malaysian Aedes aegyptipopulation}

The mutation A1007G was found in the population from Kelantan with a high frequency was observed (f $85 \%$ ). Direct neurophysiological analysis has not yet been proven, and this step is crucial in seeking evidence whether this new mutation is responsible in causing the pyrethroid resistance within the permethrin-resistant population. We hypothesize this particular mutation play a similar function as the other $k d r$ mutations since this mutation is located within one of the four specific amino acid residues in the P-region segments, DIIS6 [67]. Changes of nucleotide C to $\mathrm{G}$ at position 1007 in domain II leading to the amino acid substitution from alanine to glycine presumably give rise to the alteration of the target site in the sodium channel, hence reducing its sensitivity towards permethrin. This is further justified by the results from synergist assay that showed PBO might be considered as a partially ineffective synergist. Modification in the insect voltage gated sodium channel which normally regulates sodium ion within the gene, makes the channel less functional, hence delaying the closing of the channel $[68,69]$. The previous studies from other research groups are able to detect other regional mutations in the Asian continent. First report in Vietnam found point mutation L982W in domain II is associated with the DDT and pyrethroid cross resistance in the resistant population of Ae. aegypti [24]. In 2009, a research group from Taiwan concluded that a high resistant fold in their permethrin resistant strain is conferred by the association of a novel mutation, D1763Y with the other substitution mutation, V1016G [36]. These coexisting mutations conceivably causes synergist effect in the knockdown resistance towards permethrin. The sensitivity of the $v g s c$ gene towards permethrin resistant is reduced by 190 -fold. The presence of the point mutation, T1520I and F1534L in the domain III of the kdrgene in the Indian Ae. aegypti population might be partly responsible towards the pyrethroid resistance [39, 43]. These new mutations have yet to be functionally confirmed in the oocytes' system. Similarly, our study also has a limitation in validating this new mutation. Due to facilities constraint, we are unable to conduct the functional validation of our potential novel substitution mutation, A1007G express in the Xenopus oocytes. By conducting the experiment, we might possibly know the conformational occurrence of this new mutation in conferring pyrethroid resistance. However, high occurrence of the $1007 \mathrm{G}$ allele frequency together with the $1534 \mathrm{C}$ allele in that populations provide us an information that the co-occurrence of this new mutation with F1534C could be one of the contributing factors in the pyrethroid resistance in the Kelantan population.

Page 14/30 
To our current understanding, Lien et al. [42] discovered this new mutation in pyrethroid resistant population from Vietnam which is in line with our study. However, they did not further elucidate the role of this particular mutation. An attempt was made by a research group from United States of America to investigate this mutation in the American population of Ae. aegypti [70]. Unfortunately, this mutation could not be detected from any samples, suggesting $k d r$ allele $A 1007 \mathrm{G}$, is a part of other geographic mutations similar to V410L [40], G923V, L982W [24], I1011V/M [25], T1520I [39], F1534L [43], D1763Y [36].

Low genetic diversity was observed in the $v g s c$ gene fragment spanning point mutation S989P, A1007G, V1016G and F1534C from all localities, indicate these genes are under selection pressure which might support that knockdown resistance play a role in the pyrethroid resistance within Malaysian population of A. aegypti. This selection might be due to low polymorphism of the $v g s c$ gene fragment with low number of mutational steps between haplotypes. The similar pattern was also observed in the previous report by Ishak et al. [28], stating that F1534C mutation is under selection pressure across Malaysia, thus resulting in the reduction of genetic diversity within domain III of the $v g s c$ gene. However, this scenario was not detected in Malaysian population of Ae. albopictus since to date, there is no mutation discovered within the Malaysian strain. Currently in China, Zhou et al. [71] detected allele 1016G and 1532T might evolved from the common susceptible Ae. albopictus. In the present study, we found two kdrmutations commonly classified under the same haplotype within domain II of the $v g s c$ gene. This could be an alarming observation that could affect the authorities in controlling the population of Ae. aegypti in Malaysia due to survival adaptation of the target mosquitoes towards the same class of insecticide used in the control programme.

\section{Role of metabolic resistance in Aedes aegypti}

A major increase of the susceptibility in Balik Pulau, Penang (BP) and a slight increase of the susceptibility in the other locations after the pre-exposure towards $\mathrm{PBO}$ suggest that metabolic resistance could be involved in conferring permethrin resistance in the Malaysian population of Ae. aegypti. PBO is widely known as the most frequent synergist used with the combination of the pyrethroid insecticide in controlling the resistant mosquitoes [72]. In general, synergist like PBO can act as an enzyme inhibitor in the metabolic enzyme defence system and acts by binding the PBO metabolites to the enzyme from superfamily group of monooxygenases $\mathrm{P} 450$ and non-specific esterases, hence, resulting in the detoxification of enzyme to oxidize. Thus, the effectiveness of the pyrethroid will increase against the pyrethroid resistant mosquitoes [45]. In the present study, the pre-exposure towards PBO might be considered as an ineffective synergist against the resistant $A e$. aegypti mosquitoes as it is unable to restore full susceptibility after the exposure towards permethrin. To note, no mortality was observed in the population from Pauh, Panji (Kelantan) after the pre-exposure to PBO, suggesting that target site resistance might play a major role in this population. There might be other possible involvement of the resistance mechanism such as modification of the mosquitoes' cuticle within the Malaysian population, as the enhancement of the metabolic enzyme system can lead to the reduced penetration of the insecticides towards the cuticular insects $[73,74]$. 


\section{Conclusions}

By elucidating the resistance mechanism involved in the Malaysian strain of Aedes aegypti, we can figure out the geographical distribution of the mutations involved alongside with their frequencies. The present study reflects the high occurrence of the reported mutations and the arising of new point mutations in the $v g s c$ gene within the Malaysian permethrin-resistant strain. Henceforth, surveillance and monitoring of these mutations in the $v g s c$ gene should be conducted regularly in order to detect any possible involvement of new point mutations and also the frequency level. This act can instigate an insightfuldecision making factor on the proper usage of insecticide against the target vector which is a part of the integrated resistance management that enables the authorities to control the widespread of the resistance within the target mosquito population in Malaysia. Understanding the resistance mechanism involved in the mosquito population will enlighten the authorities to have better planning in the management of the vector control program.

\section{Declarations}

\section{Acknowledgement}

Authors would like to especially thank Ms. Nur Iwani Jamaludin for her assistance in this project. Deepest gratitude for the technical support from the Entomology \& Pest Unit of the Kelantan State Health Department in the collection of the mosquito samples. Also, we would like to thank the staff of Vector Control Research Unit (VCRU), School of Biological Sciences, Universiti Sains Malaysia for their continuous support throughout the project duration. We are also indebted to Biotechnology Laboratory (406), School of Biological Sciences for the facility provided to carry out the project. The authors would like to acknowledge these funding bodies that supported the execution of sampling work and all related molecular work throughout the course of this project; Ministry of Higher Education Fundamental Research Grant Scheme (FRGS) (203.PBIOLOGI.6711523), Universiti Sains Malaysia Short Term Grant (304.PBIOLOGI.6313188) and Saudi Arabia Ministry of Education Grant (304.PBIOLOGI.6501107.S158) for funding this project.

\section{Author's contribution}

MAMA, IHI, ISJ and NAUAB performed the mosquito collection. MAMA performed bioassay, molecular genotyping, data tabulation and analysis and wrote the first draft of manuscript. IHI conceived the study design, analysis of data and improvising the manuscript. MFFW, SL and GA perform data analysis and further improved the content of the manuscript. All authors read and approved the final manuscript.

\section{Funding}

The study was funded by Ministry of Higher Education Malaysia Fundamental Research Grant Scheme (FRGS) (203.PBIOLOGI.6711523), Universiti Sains Malaysia Short Term Grant (304.PBIOLOGI.6313188) and Saudi Arabia Ministry of Education Grant [355] (304.PBIOLOGI.6501107.S158). 
Ethics approval and consent to participate

Not applicable.

Consent of publication

Not applicable.

Competing interest

The authors declare that they have no competing interests.

Availability of data and material

All data generated or analysed during this study are included in this published article [and its supplementary information files]. The sequences determined in this study have been deposited in GenBank (GenBank accession nos. MT237357-MT237435).

Author details

${ }^{1}$ School of Biological Sciences, Universiti Sains Malaysia, 11800 Minden, Penang, Malaysia.

${ }^{2}$ School of Distance Education, Universiti Sains Malaysia, 11800 Minden, Penang, Malaysia.

${ }^{3}$ Kota Bharu Public Health Laboratory, Kelantan State Health Department, 16010 Kota Bharu, Kelantan, Malaysia.

${ }^{4}$ Vector-Borne Disease Control Programme, Penang State Health Department, 10400 Anson Road, Penang, Malaysia.

${ }^{5}$ Vector Control Research Unit, School of Biological Sciences, Universiti Sains Malaysia, 11800 Minden, Penang, Malaysia.

\section{References}

1. Burt FJ, Rolph MS, Rulli NE, Mahalingam S, Heise MT. Chikungunya: a re-emerging virus. Lancet. 2012;379(9816):662-671. doi:10.1016/S0140-6736(11)60281-X

2. Jansen CC, Beebe NW. The dengue vector Aedes aegypti: what comes next. Microb Infect. 2010;12(4):272-279. doi:10.1016/j.micinf.2009.12.011

3. Marchette NJ, Garcia R, Rudnick A. Isolation of Zika virus from Aedes aegypti mosquitoes in Malaysia. Am J Trop Med Hyg. 1969;18(3):411-415. doi:10.4269/ajtmh.1969.18.411

4. Thangamani S, Huang J, Hart CE, Guzman H, Tesh RB. Vertical transmission of Zika virus in Aedes aegypti Am J Trop Med Hyg. 2016;95(5):1169-1173. doi:10.4269/ajtmh.16-0448 
5. Reiter P. Yellow fever and dengue: a threat to Europe? Eurosurveillance. 2010;15(10):19509. doi:2807/ese.15.10.19509-en

6. Weaver SC, Reisen WK. Present and future arboviral threats. Antiviral Res. 2010; 85(2): 328-345. doi: 10.1016/j.antiviral.2009.10.008

7. Fact sheet; dengue and severe dengue. World Health Organization: Geneva; 2017. http://www.who.int/mediacentre/factsheets/fs117/en/. Accessed on 20 May 2019.

8. Leta S, Beyene TJ, De Clercq EM, Amenu K, Kraemer MUG, Revie CW. Global risk mapping for major diseases transmitted by Aedes aegypti and Aedes albopictus. Int J Infect Dis. 2018;67:25-35. doi:10.1016/j.ijid.2017.11.026

9. Powell JR. Mosquito-Borne Human Viral Diseases: Why Aedes aegypti?. Am J Trop Med Hyg. 2018;98(6):1563-1565. doi:10.4269/ajtmh.17-0866

10. Corbel V, Durot C, Achee NL, Chandre F, Coulibaly MB, David JP, et al. Second WIN International Conference on "Integrated approaches and innovative tools for combating insecticide resistance in vectors of arboviruses", October 2018, Singapore. Parasit Vectors. 2019;12(1):331. doi:10.1186/s13071-019-3591-8

11. McBride CS, Baier F, Omondi AB, Spitzer SA, Lutomiah J, Sang R, et al. Evolution of mosquito preference for humans linked to an odorant receptor. Nature. 2014;515(7526):222-227. doi:10.1038/nature13964

12. Crawford JE, Alves JM, Palmer WJ, Day JP, Sylla M, Ramasamy R, et al. Population genomics reveals that an anthropophilic population of Aedes aegypti mosquitoes in West Africa recently gave rise to American and Asian populations of this major disease vector. BMC Biol. 2017;15(1):16. doi.org/10.1186/s12915-017-0351-0

13. Situasi semasa deman denggi dan Zika di Malaysia bagi minggu 1/2017 dari 1 hingga 7 Januari 2017. Putrajaya, Malaysia: Kenyataan Akhbar Menteri Kesihatan Malaysia. 2017. http://www.moh.gov.my/index.php/database_stores/attach_download/337/870. Accessed on 20 Sep 2019.

14. Situasi semasa deman denggi, chikungunya dan Zika di Malaysia bagi minggu 5/2018 dari 28 hingga 3 Februari 2018. Putrajaya, Malaysia: Kenyataan Akhbar Menteri Kesihatan Malaysia. 2018. http://www.moh.gov.my/index.php/database_stores/attach_download/337/975. Accessed on 20 Sep 2019.

15. Situasi semasa deman denggi, Zika dan chikungunya di Malaysia bagi minggu 36/2019 dari 1 hingga 7 September 2019. Putrajaya, Malaysia: Kenyataan Akhbar Menteri Kesihatan Malaysia. 2019. http://www.moh.gov.my/index.php/database_stores/attach_download/337/1232. Accessed on 20 Sep 2019.

16. Wichmann O, Vannice K, Asturias EJ, de Albuquerque Luna EJ, Longini I, Lopez AL, et al. Liveattenuated tetravalent dengue vaccines: The needs and challenges of post-licensure evaluation of vaccine safety and effectiveness. Vaccine. 2017;35(42):5535-5542. doi:10.1016/j.vaccine.2017.08.066 
17. Dengue: Guidelines for diagnosis, treatment, prevention and control: New edition. Geneva, World Health Organization; 2009.

18. Yap HH, Zairi J, Lee YW, Adanan CR. Mosquito Control. In: Lee CY, Yap HH, Chong NL, Zairi J. (eds.), Urban pest control, a Malaysian perspective, 2nd edn. Universiti Sains Malaysia, Penang, Malaysia; 2003. p. 43-53.

19. Global insecticide use for vector-borne disease control- A 10-year assessment (2000-2009), 5th ed.; World Health Organization: Geneva, Switzerland; 2016.

20. Ranson H, N'guessan R, Lines J, Moiroux N, Nkuni Z, Corbel V. Pyrethroid resistance in African anopheline mosquitoes: what are the implications for malaria control?. Trends Parasitol. 2011;27(2):91-98. doi:10.1016/j.pt.2010.08.004

21. Bariami V, Jones CM, Poupardin R, Vontas J, Ranson H. Gene amplification, ABC transporters and cytochrome P450s: unraveling the molecular basis of pyrethroid resistance in the dengue vector, Aedes aegypti. PLoS Negl Trop Dis. 2012;6(6):e1692. doi:10.1371/journal.pntd.0001692

22. Hemingway J, Boddington RG, Harris J, Dunbar SJ. Mechanisms of insecticide resistance in Aedes aegypti (L.) (Diptera: Culicidae) from Puerto Rico. Bull Entomol Res. 1989;79(1):123-130. doi:10.1017/S0007485300018630

23. Prevention and management of insecticide resistance in vectors of public health importance. 2010. http://www.afpmb.org/sites/default/files/whatsnew/2011/irac manual.pdf. Accessed on 10 Sep 2019.

24. Brengues C, Hawkes NJ, Chandre F, McCarroll L, Duchon S, Guillet P, et al. Pyrethroid and DDT crossresistance in Aedes aegypti is correlated with novel mutations in the voltage-gated sodium channel gene. Med Vet Entomol. 2003;17(1):87-94. doi:10.1046/j.1365-2915.2003.00412.x

25. Saavedra-Rodriguez K, Urdaneta-Marquez L, Rajatileka S, Moulton M, Flores AE, Fernandez-Salas I, et al. A mutation in the voltage-gated sodium channel gene associated with pyrethroid resistance in Latin American Aedes aegypti. Insect Mol Biol. 2007;16(6):785-798. doi:10.1111/j.13652583.2007.00774.x

26. Hirata K, Komagata O, Itokawa K, Yamamoto A, Tomita T, Kasai S. A single crossing-over event in voltage-sensitive $\mathrm{Na}+$ channel genes may cause critical failure of dengue mosquito control by insecticides. PLoS Negl Trop Dis. 2014;8(8):e3085. doi:10.1371/journal.pntd.0003085

27. Haddi K, Tomé HVV, Du Y, Valbon WR, Nomura Y, Martins GF, et al. Detection of a new pyrethroid resistance mutation (V410L) in the sodium channel of Aedes aegypti. a potential challenge for mosquito control. Sci Rep. 2017;7:46549. doi:10.1038/srep46549

28. Ishak IH, Jaal Z, Ranson H, Wondji, CS. Contrasting patterns of insecticide resistance and knockdown resistance (kdr) in the dengue vectors Aedes aegypti and Aedes albopictus from Malaysia. Parasit Vectors. 2015; 8:181. doi: 10.1186/s13071-015-0797-2

29. Rasli R, Lee HL, Wasi Ahmad N, Fikri SFF, Ali R, Muhamed KA, et al. Susceptibility status and resistance mechanisms in permethrin-selected, laboratory susceptible and field-collected Aedes aegypti from Malaysia. Insects. 2018;9(2):43. doi:10.3390/insects9020043 
30. Leong CS, Vythilingam I, Liew JW, Wong ML, Wan-Yusoff WS, Lau YL. Enzymatic and molecular characterization of insecticide resistance mechanisms in field populations of Aedes aegyptifrom Selangor, Malaysia. Parasit Vectors. 2019;12(1):236. doi:10.1186/s13071-019-3472-1

31. Kawada H, Higa Y, Komagata O, Kasai S, Tomita T, Thi Yen N, et al. Widespread distribution of a newly found point mutation in voltage-gated sodium channel in pyrethroid-resistant Aedes aegypti populations in Vietnam. PLoS Negl Trop Dis. 2009;(10):e527. doi:10.1371/journal.pntd.0000527

32. Stenhouse SA, Plernsub S, Yanola J, Lumjuan N, Dantrakool A, Choochote W, et al. Detection of the V1016G mutation in the voltage-gated sodium channel gene of Aedes aegypti (Diptera: Culicidae) by allele-specific PCR assay, and its distribution and effect on deltamethrin resistance in Thailand. Parasit Vectors. 2013;6(1):253. doi:10.1186/1756-3305-6-253

33. Kasai S, Komagata O, Itokawa K, Shono T, $\mathrm{Ng}$ LC, Kobayashi M et al. Mechanisms of pyrethroid resistance in the dengue mosquito vector, Aedes aegypti. target site insensitivity, penetration, and metabolism. PLoS Negl Trop Dis. 2014;8(6):e2948. doi:10.1371/journal.pntd.0002948

34. Kawada H, Oo SZ, Thaung S, Kawashima E, Maung YN, Thu HM, et al. Co-occurrence of point mutations in the voltage-gated sodium channel of pyrethroid-resistant Aedes aegypti populations in Myanmar. PLoS Negl Trop Dis. 2014;(7):e3032. doi:10.1371/journal.pntd.0003032

35. Wuliandari JR, Lee SF, White VL, Tantowijoyo W, Hoffmann AA, Endersby-Harshman NM. Association between three mutations, F1565C, V1023G and S996P, in the voltage-sensitive sodium channel gene and knockdown resistance in Aedes aegypti from Yogyakarta, Indonesia. Insects. 2015;6(3):658-685. doi:10.3390/insects6030658

36. Chang C, Shen WK, Wang TT, Lin YH, Hsu EL, Dai SM. A novel amino acid substitution in a voltagegated sodium channel is associated with knockdown resistance to permethrin in Aedes aegypti. Insect Biochem Mol Biol. 2009;39(4):272-278. doi:10.1016/j.ibmb.2009.01.001

37. Srisawat R, Komalamisra N, Eshita Y, Zheng M, Ono K, Itoh T, et al. Point mutations in domain II of the voltage-gated sodium channel gene in deltamethrin-resistant Aedes aegypti (diptera: culicidae). Appl Entomol Zool. 2010; 45(2):275-282. doi: 10.1303/aez.2010.275

38. Hu Z, Du Y, Nomura Y, Dong K. A sodium channel mutation identified in Aedes aegypti selectively reduces cockroach sodium channel sensitivity to type I, but not type II pyrethroids. Insect Biochem Mol Biol. 2011;41(1):9-13. doi:10.1016/j.ibmb.2010.09.005

39. Kushwah RBS, Dykes CL, Kapoor N, Adak T, Singh OP. Pyrethroid-resistance and presence of two knockdown resistance (kdr) mutations, F1534C and a novel mutation T1520I, in Indian Aedes aegypti. PLoS Negl Trop Dis. 2015;9(1): e3332. doi:10.1371/journal.pntd.0003332

40. Saavedra-Rodriguez K, Maloof FV, Campbell CL, Garcia-Rejon J, Lenhart A, Penilla P, et al. Parallel evolution of vgsc mutations at domains IS6, IIS6 and IIIS6 in pyrethroid resistant Aedes aegypti from Mexico. Sci Rep. 2018;8(1):6747. doi:10.1038/s41598-018-25222-0

41. Yanola J, Somboon P, Walton C, Nachaiwieng W, Somwang P, Prapanthadara LA. High-throughput assays for detection of the $\mathrm{F} 1534 \mathrm{C}$ mutation in the voltage-gated sodium channel gene in 
permethrin-resistant Aedes aegypti and the distribution of this mutation throughout Thailand. Trop Med Int Health. 2011;16(4):501-509. doi:10.1111/j.1365-3156.2011.02725.x

42. Lien NTK, Ngoc NTH, Hien NT, Hoang NH, Binh NTH. Two novel mutations in the voltage-gated sodium channel associated with knockdown resistance $(\mathrm{kdr})$ in the dengue vector Aedes aegypti in Vietnam. J Vector Ecol. 2018;43(1):184-189. doi:10.1111/jvec.12298

43. Kushwah RBS, Kaur T, Dykes CL, Kumar HV, Kapoor N, Singh OP. A new knockdown resistance (kdr) mutation, F1534L, in the voltage-gated sodium channel of Aedes aegypti, co-occurring with F1534C, S989P and V1016G. Parasit Vectors. 2020;13,327 doi:10.1186/s13071-020-04201-3

44. Monitoring and managing insecticide resistance in Aedes mosquito populations: Interim guidance for entomologists. WHO/ZIKV/VC/16.1. World Health Organization, Geneva, Switzerland. 2016.

45. Bingham G, Strode C, Tran L, Khoa PT, Jamet HP. Can piperonyl butoxide enhance the efficacy of pyrethroids against pyrethroid-resistant Aedes aegypti? Trop. Med. Int. Health. 2011;16(4):492-500. doi: 10.1111/j.1365-3156.2010.02717.x

46. Livak KJ. Organization and mapping of a sequence on the Drosophila melanogaster $X$ and $Y$ chromosomes that is transcribed during spermatogenesis. Genetics. 1984;107(4):611-634

47. Tamura K, Stecher G, Peterson D, Filipski A, Kumar S. MEGA6: Molecular Evolutionary Genetics Analysis version 6.0. Mol Biol Evol. 2013;30(12):2725-2729. doi:10.1093/molbev/mst197

48. Swofford DL. PAUP*. Phylogenetic analysis using parsimony (* and other methods). Version 4. Sinauer Associates, Sunderland; 2003.

49. Clement M, Snell Q, Walker P, Posada D, Crandall K. (2002). TCS: Estimating gene genealogies. Parallel and Distributed Processing Symposium, International Proceedings. 2002;2,184.

50. Leigh JW, Bryant D. PopART: Full-feature software for haplotype network construction. Methods Ecol. Evol. 2015;6(9):1110-1116. doi: 10.1111/2041-210X.12410

51. Singh OP, Bali P, Hemingway J, Subbarao SK, Dash AP, Adak T. PCR-based methods for the detection of L1014 kdr mutation in Anopheles culicifacies sensu lato. Malar J. 2009;8:154. doi:10.1186/14752875-8-154

52. Amelia-Yap ZH, Chen CD, Sofian-Azirun M, Low VL. Pyrethroid resistance in the dengue vector Aedes aegypti in Southeast Asia: present situation and prospects for management. Parasit Vectors. 2018;11(1):332. doi:10.1186/s13071-018-2899-0

53. Young S, Gunning RV, Moores DD. The effect of pre-treatment with piperonyl butoxide on pyrethroid efficacy against insecticide-resistant Helicoverpa armigera (Lepidoptera: Noctuidae) and Bemisia tabaci (Sternorrhyncha: Aleyrodidae). Pest Manag Sci. 2006;62(2):114-119. doi: 10.1002/ps.1127

54. Chuaycharoensuk T, Juntarajumnong W, Boonyuan W, Bangs MJ, Akratanakul P, Thammapalo S, et al. Frequency of pyrethroid resistance in Aedes aegypti and Aedes albopictus (Diptera: Culicidae) in Thailand. J. Vector Ecol. 2011;36(1):204-12. doi: 10.1111/j.1948-7134.2011.00158.x

55. Koou SY, Chong CS, Vythilingam I, Lee CY, Ng LC. (2014). Insecticide resistance and its underlying mechanisms in field populations of Aedes aegypti adults (Diptera: Culicidae) in Singapore. Parasit Vectors. 2014;7:471. doi:10.1186/s13071-014-0471-0 
56. Boyer S, Lopes S. WHOPES methods to test insecticide susceptibility of four Aedes aegypti field populations in Cambodia. Dengue integrated vector management: dissemination and policy uptake workshop: Phnom Penh; 2016.

57. Sayono S, Hidayati AP, Fahri S, Sumanto D, Dharmana E, Hadisaputro S, et al. Distribution of voltagegated sodium channel (Nav) alleles among the Aedes aegypti populations in Central Java province and its association with resistance to pyrethroid insecticides. PLoS One. 2016;1(3):e0150577. doi:10.1371/journal.pone.0150577

58. Hamid PH, Prastowo J, Ghiffari A, Taubert A, Hermosilla C. Aedes aegypti resistance development to commonly used insecticides in Jakarta, Indonesia. PLoS One. 2017;12(12):e0189680. doi:10.1371/journal.pone.0189680

59. Kongmee M, Thanispong K, Sathantriphop S, Sukkanon C, Bangs MJ, Chareonviriyaphap T. Enhanced mortality in deltamethrin-resistant Aedes aegypti in Thailand using a piperonyl butoxide synergist. Acta Trop. 2019;189:76-83. doi:10.1016/j.actatropica.2018.09.025

60. Hasan HA, Jaal Z, Ranson H, McCall P. Pyrethroid and organophosphate susceptibility status of Aedes aegypti (Linnaeus) and Aedes albopictus (Skuse) in Penang. Malaysia. Int J Entomol Res. 2016;3:91-95.

61. Yap HH, Lee YW, Zairi, J. Chemical control of mosquitoes, In: Ng FSP, Yong HS. (eds.), Mosquitoes and mosquito-borne diseases: biology, surveillance, control, personal and public protection measures. Academic of Sciences Malaysia, Kuala Lumpur, Malaysia; 2000. p. 197-210.

62. Ong SQ. Dengue vector control in Malaysia: a review for current and alternative strategies. Sains Malays. 2016;45(5):777-785.

63. Chin AC, Chen CD, Low VL, Lee HL, Azidah AA, Lau KW, et al. Comparative efficacy of commercial mosquito coils against Aedes aegypti (Diptera: Culicidae) in Malaysia: A nationwide report. J Econ Entomol. 2017 Oct 1;110(5):2247-2251. doi: 10.1093/jee/tox183.

64. Lau KW, Chen CD, Lee HL, Sofian-Azirun M. Evaluation of insect growth regulators, temephos and Bacillus thuringiensis israelensis against Aedes aegypti $(\mathrm{L})$ in plastic containers. Trop. Biomed. 2015;32(4):684-692.

65. Yunta C, Hemmings K, Stevenson B, Koekemoer LL, Matambo T, Pignatelli P, et al. Cross-resistance profiles of malaria mosquito $\mathrm{P} 450$ s associated with pyrethroid resistance against WHO insecticides. Pestic Biochem Phys. 2019;161:61-67. doi:10.1016/j.pestbp.2019.06.007

66. Test procedures for insecticide resistance monitoring in malaria vector mosquitoes. Second Edition. Programme GM, editor. Geneva, Switzerland. 2016.

67. Favre I, Moczydlowski E, Schild L. On the structural basis for ionic selectivity among $\mathrm{Na}+, \mathrm{K}+$, and Ca2+ in the voltage-gated sodium channel. Biophys J. 1996;71(6):3110-3125. doi:10.1016/S00063495(96)79505-X

68. Zlotkin E. The insect voltage-gated sodium channel as target of insecticides. Annu Rev Entomol. 1999;44:429-455. doi: 10.1146/annurev.ento.44.1.429 
69. Soderlund DM, Knipple DC. The molecular biology of knockdown resistance to pyrethroid insecticides. Insect Biochem Mol Biol. 2003;33(6):563-577. doi:10.1016/s0965-1748(03)00023-7

70. Fan Y, O'Grady P, Yoshimizu M, Ponlawat A, Kaufman PE, Scott JG. Evidence for both sequential mutations and recombination in the evolution of kdr alleles in Aedes aegypti. PLoS Negl Trop Dis. 2020;14(4):e0008154. doi:10.1371/journal.pntd.0008154

71. Zhou X, Yang C, Liu N, Li M, Tong Y, Zeng X, et al. Knockdown resistance (kdr) mutations within seventeen field populations of Aedes albopictus from Beijing China: first report of a novel V1016G mutation and evolutionary origins of kdr haplotypes. Parasit Vectors. 2019;12(1):180. doi:10.1186/s13071-019-3423-x

72. Sangba ML, Deketramete T, Wango SP, Kazanji M, Akogbeto M, Ndiath MO. Insecticide resistance status of the Anopheles funestus population in Central African Republic: a challenge in the war. Parasit \& Vectors. 2016;9:230. doi: 10.1186/s13071-016-1510-9

73. Sun YP, Johnson ER. Quasi-synergism and penetration of insecticides. J Econ Entomol. 1972;65(2):349-53. doi: 10.1093/jee/65.2.349

74. Ahmad M, Denholm I, Bromilow RH. Delayed cuticular penetration and enhanced metabolism of deltamethrin in pyrethroid-resistant strains of Helicoverpa armigera from China and Pakistan. Pest Manag. Sci. 2006;62(9):805-810. doi:10.1002/ps.1225

\section{Tables}

Table 1 Correlation of genotype S989P with the resistance phenotype towards permethrin for the field strain Aedes aegypti. 


\begin{tabular}{|c|c|c|c|c|c|c|c|c|c|c|c|}
\hline \multirow[t]{3}{*}{ States } & \multirow[t]{3}{*}{ Location } & \multirow{3}{*}{$\begin{array}{c}\text { Phenotype } \\
\text { Status }\end{array}$} & \multirow[t]{3}{*}{$\mathrm{n}$} & \multicolumn{8}{|c|}{ S989P } \\
\hline & & & & \multicolumn{3}{|c|}{ Genotype } & \multicolumn{2}{|c|}{ Alleles } & \multirow{2}{*}{$\begin{array}{c}\text { Frequency } \\
\text { P allele }\end{array}$} & \multirow{2}{*}{$\begin{array}{l}\text { Odd } \\
\text { ratio } \\
\text { (OR) }\end{array}$} & \multirow{2}{*}{$\begin{array}{c}\text { Fisher's } \\
\text { exact } \\
\text { test } \\
\text { (p- } \\
\text { value) }\end{array}$} \\
\hline & & & & $\mathrm{S} / \mathrm{S}$ & $\mathrm{S} / \mathrm{P}$ & $\mathrm{P} / \mathrm{P}$ & $\underline{\mathrm{TCC}}$ & $\underline{\mathrm{CCC}}$ & & & \\
\hline \multirow[t]{4}{*}{ Penang } & \multirow{2}{*}{$\begin{array}{l}\text { Sungai Dua } \\
\text { (SD) }\end{array}$} & Resistant & 3 & 0 & 2 & 1 & 2 & 4 & 0.667 & \multirow[t]{2}{*}{0} & \multirow[t]{2}{*}{0.333} \\
\hline & & Susceptible & 2 & 0 & 0 & 2 & 0 & 4 & 1 & & \\
\hline & \multirow{2}{*}{$\begin{array}{l}\text { Balik Pulau } \\
\text { (BP) }\end{array}$} & Resistant & 4 & 0 & 0 & 4 & 0 & 8 & 1 & & \multirow[t]{2}{*}{0.165} \\
\hline & & Susceptible & 3 & 1 & 0 & 2 & 2 & 4 & 0.667 & & \\
\hline \multirow[t]{4}{*}{ Selangor } & \multirow{2}{*}{$\begin{array}{c}\text { Alam Budiman } \\
\text { (AB) }\end{array}$} & Resistant & 4 & 2 & 2 & 0 & 6 & 2 & 0.25 & & \multirow[t]{2}{*}{0.424} \\
\hline & & Susceptible & 2 & 2 & 0 & 0 & 4 & 0 & 0 & & \\
\hline & \multirow[t]{2}{*}{ TUDM (TDM) } & Resistant & 3 & 3 & 0 & 0 & 6 & 0 & 0 & \multirow[t]{2}{*}{0} & \multirow[t]{2}{*}{0.571} \\
\hline & & Susceptible & 4 & 3 & 1 & 0 & 7 & 1 & 0.125 & & \\
\hline \multirow[t]{4}{*}{ Kelantan } & \multirow{2}{*}{$\begin{array}{c}\text { Pauh, Panji } \\
\text { (PNJ) }\end{array}$} & Resistant & 10 & 10 & 0 & 0 & 20 & 0 & 0 & \multirow[t]{2}{*}{$\mathrm{N} / \mathrm{A}$} & \multirow[t]{2}{*}{0.999} \\
\hline & & Susceptible & - & - & - & - & - & - & - & & \\
\hline & \multirow{2}{*}{$\begin{array}{c}\text { Flat Buluh } \\
\text { Kubu (FLT) }\end{array}$} & Resistant & 10 & 9 & 0 & 1 & 18 & 2 & 0.1 & & \multirow[t]{2}{*}{0.823} \\
\hline & & Susceptible & 1 & 1 & 0 & 0 & 2 & 0 & 0 & & \\
\hline
\end{tabular}

"-" No individuals died during adult bioassay, thus the genotype and the allelic frequency cannot be determined. N/A indicates that it could not be determined because no individual died for susceptible phenotype. suggests a high risk for the association between phenotype and genotype.

Table 2 Results on the association of V1016G allele with the insecticide resistance phenotype.

"-" No individuals died during adult bioassay, thus the genotype and the allelic frequency cannot be determined. N/A indicates that it could not be determined because no individual died for susceptible phenotype. suggests a high risk for the association between phenotype and genotype.

Table 3 Results on the association of F1534C allele with the insecticide resistance phenotype. 


\begin{tabular}{|c|c|c|c|c|c|c|c|c|c|c|c|}
\hline \multirow[t]{3}{*}{ States } & \multirow[t]{3}{*}{ Location } & \multirow{3}{*}{$\begin{array}{l}\text { Phenotype } \\
\text { Status }\end{array}$} & \multirow[t]{3}{*}{$\mathrm{n}$} & \multicolumn{8}{|c|}{ V1016G } \\
\hline & & & & \multicolumn{3}{|c|}{ Genotype } & \multicolumn{2}{|c|}{ Alleles } & \multirow{2}{*}{$\begin{array}{l}\text { Frequency } \\
\text { G allele }\end{array}$} & \multirow{2}{*}{$\begin{array}{l}\text { Odd } \\
\text { ratio } \\
(\mathrm{OR})\end{array}$} & \multirow{2}{*}{$\begin{array}{c}\text { Fisher's } \\
\text { exact } \\
\text { test } \\
\text { (p- } \\
\text { value) } \\
\end{array}$} \\
\hline & & & & $\mathrm{V} / \mathrm{V}$ & $\mathrm{V} / \mathrm{G}$ & $\mathrm{G} / \mathrm{G}$ & GTA & GGA & & & \\
\hline \multirow[t]{4}{*}{ Penang } & \multirow{2}{*}{$\begin{array}{c}\text { Sungai Dua } \\
\text { (SD) }\end{array}$} & Resistant & 20 & 14 & 3 & 3 & 31 & 9 & 0.225 & \multirow[t]{2}{*}{0.29} & \multirow[t]{2}{*}{0.03} \\
\hline & & Susceptible & 12 & 2 & 8 & 2 & 12 & 12 & 0.5 & & \\
\hline & \multirow{2}{*}{$\begin{array}{c}\text { Balik Pulau } \\
\text { (BP) }\end{array}$} & Resistant & 20 & 4 & 10 & 6 & 18 & 22 & 0.55 & \multirow[t]{2}{*}{1.667} & \multirow[t]{2}{*}{0.450} \\
\hline & & Susceptible & 13 & 5 & 5 & 3 & 15 & 11 & 0.538 & & \\
\hline \multirow[t]{4}{*}{ Selangor } & \multirow{2}{*}{$\begin{array}{c}\text { Alam } \\
\text { Budiman } \\
(\mathrm{AB})\end{array}$} & Resistant & 20 & 14 & 2 & 4 & 30 & 10 & 0.25 & & \multirow[t]{2}{*}{0.315} \\
\hline & & Susceptible & 3 & 3 & 0 & 0 & 6 & 0 & 0 & & \\
\hline & \multirow{2}{*}{$\begin{array}{l}\text { TUDM } \\
\text { (TDM) }\end{array}$} & Resistant & 20 & 7 & 9 & 4 & 23 & 17 & 0.425 & \multirow[t]{2}{*}{3.696} & \multirow[t]{2}{*}{0.0234} \\
\hline & & Susceptible & 18 & 12 & 6 & 0 & 30 & 6 & 0.167 & & \\
\hline \multirow[t]{4}{*}{ Kelantan } & \multirow{2}{*}{$\begin{array}{l}\text { Pauh, Panji } \\
\text { (PNJ) }\end{array}$} & Resistant & 20 & 10 & 10 & 0 & 30 & 10 & 0.25 & \multirow[t]{2}{*}{$\mathrm{N} / \mathrm{A}$} & \multirow[t]{2}{*}{0.999} \\
\hline & & Susceptible & 0 & - & - & - & - & - & - & & \\
\hline & \multirow{2}{*}{$\begin{array}{c}\text { Flat Buluh } \\
\text { Kubu } \\
\text { (FLT) }\end{array}$} & Resistant & 20 & 18 & 2 & 0 & 38 & 2 & 0.05 & & \multirow[t]{2}{*}{0.999} \\
\hline & & Susceptible & 1 & 1 & 0 & 0 & 2 & 0 & 0 & & \\
\hline
\end{tabular}

"-" No individuals died during adult bioassay, thus the genotype and the allelic frequency cannot be determined. N/A indicates that it could not be determined because no individual died for susceptible phenotype. suggests a high risk for the association between phenotype and genotype.

Table 4 Association of potential novel mutation A1007G allele with the insecticide resistance phenotype.

"-" No individuals died during adult bioassay, thus the genotype and the allelic frequency cannot be determined. N/A indicates that it could not be determined because no individual died for susceptible phenotype. suggests a high risk for the association between phenotype and genotype.

Table 5 Summary statistics of the polymorphism at the $v g S C$ fragment of domain II and III in the Malaysian population of Ae. aegypti. 


\begin{tabular}{|c|c|c|c|c|c|c|c|c|c|c|c|}
\hline \multirow[t]{3}{*}{ States } & \multirow[t]{3}{*}{ Location } & \multirow{3}{*}{$\begin{array}{c}\text { Phenotype } \\
\text { Status }\end{array}$} & \multirow[t]{3}{*}{$\mathrm{n}$} & \multicolumn{8}{|c|}{ F1534C } \\
\hline & & & & \multicolumn{3}{|c|}{ Genotype } & \multicolumn{2}{|c|}{ Alleles } & \multirow{2}{*}{$\begin{array}{l}\text { Frequency } \\
\text { C allele }\end{array}$} & \multirow{2}{*}{$\begin{array}{l}\text { Odd } \\
\text { ratio } \\
(\mathrm{OR})\end{array}$} & \multirow{2}{*}{$\begin{array}{c}\text { Fisher's } \\
\text { exact } \\
\text { test } \\
\text { (p- } \\
\text { value) }\end{array}$} \\
\hline & & & & $\mathrm{F} / \mathrm{F}$ & $\mathrm{F} / \mathrm{C}$ & $\mathrm{C} / \mathrm{C}$ & TTC & TGGC & & & \\
\hline \multirow[t]{4}{*}{ Penang } & \multirow{2}{*}{$\begin{array}{c}\text { Sungai } \\
\text { Dua } \\
\text { (SD) }\end{array}$} & Resistant & 20 & 7 & 7 & 6 & 21 & 19 & 0.475 & \multirow[t]{2}{*}{1.069} & \multirow[t]{2}{*}{0.999} \\
\hline & & Susceptible & 12 & 3 & 7 & 2 & 13 & 11 & 0.458 & & \\
\hline & \multirow{2}{*}{$\begin{array}{c}\text { Balik Pulau } \\
\text { (BP) }\end{array}$} & Resistant & 20 & 3 & 12 & 5 & 18 & 22 & 0.55 & \multirow[t]{2}{*}{3.318} & \multirow[t]{2}{*}{0.042} \\
\hline & & Susceptible & 13 & 8 & 3 & 2 & 19 & 7 & 0.269 & & \\
\hline \multirow[t]{4}{*}{ Selangor } & \multirow{2}{*}{$\begin{array}{c}\text { Alam } \\
\text { Budiman } \\
(\mathrm{AB})\end{array}$} & Resistant & 20 & 1 & 15 & 4 & 17 & 23 & 0.575 & & \multirow[t]{2}{*}{0.022} \\
\hline & & Susceptible & 3 & 3 & 0 & 0 & 6 & 0 & 0 & & \\
\hline & \multirow{2}{*}{$\begin{array}{l}\text { TUDM } \\
(\mathrm{TDM})\end{array}$} & Resistant & 20 & 8 & 11 & 1 & 27 & 13 & 0.325 & \multirow[t]{2}{*}{16.852} & \multirow[t]{2}{*}{0.001} \\
\hline & & Susceptible & 18 & 17 & 1 & 0 & 35 & 1 & 0.028 & & \\
\hline \multirow[t]{4}{*}{ Kelantan } & \multirow{2}{*}{$\begin{array}{l}\text { Pauh, Panji } \\
\text { (PNJ) }\end{array}$} & Resistant & 20 & 0 & 1 & 19 & 1 & 39 & 0.975 & \multirow[t]{2}{*}{$\mathrm{N} / \mathrm{A}$} & \multirow[t]{2}{*}{0.999} \\
\hline & & Susceptible & 0 & - & - & - & - & - & - & & \\
\hline & \multirow{2}{*}{$\begin{array}{c}\text { Flat Buluh } \\
\text { Kubu } \\
\text { (FLT) }\end{array}$} & Resistant & 20 & 1 & 1 & 18 & 3 & 37 & 0.925 & & \multirow[t]{2}{*}{0.02} \\
\hline & & Susceptible & 1 & 1 & 0 & 0 & 2 & 0 & 0 & & \\
\hline
\end{tabular}

\begin{tabular}{|c|c|c|c|c|c|c|c|c|c|c|c|}
\hline \multirow[t]{3}{*}{ States } & \multirow[t]{3}{*}{ Location } & \multirow{3}{*}{$\begin{array}{l}\text { Phenotype } \\
\text { Status }\end{array}$} & \multirow[t]{3}{*}{$\mathrm{n}$} & \multicolumn{8}{|c|}{ A1007G } \\
\hline & & & & \multicolumn{3}{|c|}{ Genotype } & \multicolumn{2}{|c|}{ Alleles } & \multirow{2}{*}{$\begin{array}{l}\text { Frequency } \\
\text { G allele }\end{array}$} & \multirow{2}{*}{$\begin{array}{l}\text { Odd } \\
\text { ratio } \\
(\mathrm{OR})\end{array}$} & \multirow{2}{*}{$\begin{array}{c}\text { Fisher's } \\
\text { exact } \\
\text { test } \\
\text { (p- } \\
\text { value) }\end{array}$} \\
\hline & & & & $\overline{\mathrm{A} / \mathrm{A}}$ & $\mathrm{A} / \mathrm{G}$ & $\mathrm{G} / \mathrm{G}$ & Gㅁㄷ & GGC & & & \\
\hline \multirow[t]{4}{*}{ Kelantan } & \multirow{2}{*}{$\begin{array}{c}\text { Pauh, Panji } \\
\text { (PNJ) }\end{array}$} & Resistant & 10 & 0 & 3 & 7 & 3 & 17 & 0.85 & \multirow[t]{2}{*}{$\mathrm{N} / \mathrm{A}$} & \multirow[t]{2}{*}{0.999} \\
\hline & & Susceptible & - & - & - & - & - & - & - & & \\
\hline & \multirow{2}{*}{$\begin{array}{c}\text { Flat Buluh } \\
\text { Kubu } \\
\text { (FLT) }\end{array}$} & Resistant & 10 & 1 & 0 & 9 & 2 & 18 & 0.90 & & \multirow[t]{2}{*}{0.026} \\
\hline & & Susceptible & 1 & 1 & 0 & 0 & 2 & 0 & 0 & & \\
\hline
\end{tabular}

\begin{tabular}{cccccc}
\hline Domain & $\mathbf{N}$ & PS & & $\mathbf{D}$ & $\boldsymbol{\Phi}_{\text {ST }}$ \\
\hline DII & 47 & 5 & $9.42961 \mathrm{e}+06$ & $3.3123 \mathrm{e}+09^{\mathrm{ns}}$ & 0.77635 \\
DIII & 34 & 1 & 0.0016929 & $1.3518^{\mathrm{ns}}$ & 0.73996 \\
\hline
\end{tabular}

$\mathrm{N}$, number of samples; PS, number of polymorphic sites; , nucleotide diversity; $\mathrm{D}$, Tajima's D $(P<0.05) ; \Phi_{\mathrm{ST}}$, AMOVA; ns, not significant 
Figures

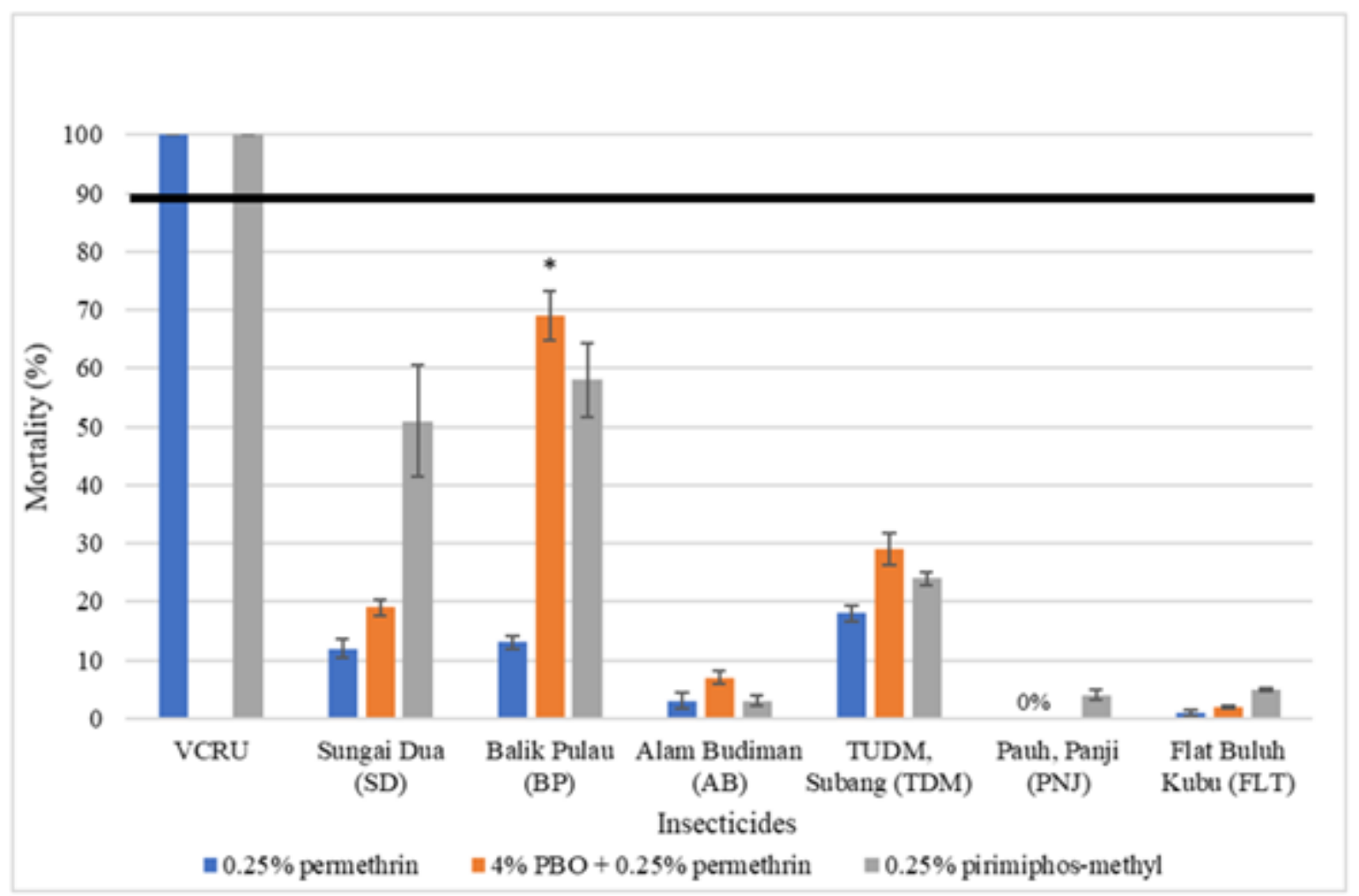

\section{Figure 1}

Percentage mortality of female Aedes aegypti from various locations across Malaysia towards two classes of insecticides and a synergist. Error bars represent 95\% confidence interval (CI). Black horizontal line indicates resistant threshold level (mortality less than $90 \%$ is considered phenotypically resistant; WHO, 2016). Statistically significant difference for the exposure with and without PBO is indicated by ${ }^{*} \mathrm{P}<0.05 .0 \%$ indicates no mosquitoes died 24 hours post-exposure. 


\begin{tabular}{|c|c|c|c|c|c|c|c|c|}
\hline Musca domestica & 972 & MHSFMIVIRV & LOGEWIESNK & DCMYVGDVSC & IPFFLATVVI & 1011 & & \\
\hline Aedes aegypti China & 979 & MHSFMIVFRV & LOGEWIESMK & DCMIVGDVSC & IPFFLATVVI & 1018 & & \\
\hline AB_PYR_R_DII & & MHSFMIVERV & LOGEWIEPNK & DCMIVGDVSC & IPFFLATVYI & & & \\
\hline AB_PYR_S_DII & & MHSFMIVFRV & LOGEWIESNW & DCMLVGDVSC & IPFFLATVVI & & & \\
\hline TDM_PYR_R_DII & & MHSFNIVFRV & LOGEWIESNW & DCMLVGDVSC & IPFFLATVVI & & & \\
\hline TLM_PYR_S_DII & & MHSFMIVFRV & LOGEWIESNK & DCMIVGDVSC & IPFFLATVVI & & & \\
\hline SD_PYR_R_DII & & MHSFMIVFRV & LOGEWIEPNK & DCMIVGDVSC & IDFFLATVVI & & & \\
\hline SD_PYR_S_DII & & MHSFMIVFRV & LOGEWIEPNK & DCMIVGDVSC & IPFFLATVVI & & & \\
\hline BP_PYR_R_DII & & MHSFMIVERV & LOGEWIEPNW & DCMIVGDVSC & IPFFLATVVI & & & \\
\hline BP_PYR_S_DII & & MHSFNIVFRV & LCGEWIEPNW & DCMLVGDVSC & IPFFLATVVI & & & \\
\hline PNJ_PYR_R_DII & & MHSFMIVERV & LCGEWIESMW & DCMLVGDVSC & IPFFLGTVVI & & & \\
\hline FLT_PYR_R_DII & & MHSFMIVFRV & LOGEWIESNK & DCMIVGDVSC & IPFFLGTVVI & & & \\
\hline FLI_PYR_S_DII & & MHSFMIVRRV & LOGEWIESN & DCMIVGDVSC & IDFFLATVVI & & & \\
\hline & & $* * \star * * * * * * *$ & $\star * \star * \star * * * *$ & $* * * * * * * * *$ & $* * * * * * * * *$ & & & \\
\hline Musca domestica & & GNLVVLNLEL & AHLLSNPGSS & SLSAPTADND & TNKIAEAFNR & I & NIADCF & 1068 \\
\hline Aedes aegypti China & & GNLVVLNLFL & AILLSNFGSS & SLSADTADNE & TNKIAEAFNR & ISRFSNWIKS & NIANAI & 1074 \\
\hline AB_PYR_R_DII & & GNLVGLNLFL & ALLLSNFGSS & SLSAPTADNE & TNKIAEAFNR & ISRFSNWIKS & NIANAI & \\
\hline AB_PYR_S_DII & & GNLVVLNLEL & AILISNFGSS & SLSAPTADNE & TNKIAEAFNR & ISRFSNWIKS & NIANAL & \\
\hline TLN_PYR_R_DII & & GNLVGLNLEL & AILISNFGSS & SLSAPTADNE & TNKIAEAFNR & ISRFSNKIKS & NIANAL & \\
\hline TCM_PYR_S_DII & & GNLVGLNLFL & AILLSNPGSS & SLSAPTADNE & TNKIAEAFNR & ISRFSNWIKS & NIANAL & \\
\hline SD_PYR_R_DII & & GNLVGLNLFL & ALILSNFGSS & SLSAPTADNE & TNKIAEAFNR & ISRFSNWIKS & NIANAL & \\
\hline SD_PYR_S_DII & & GNLVGLNLFL & ALLLSNFGSS & SLSAPTADNE & TNKIAEAFNR & ISRFSNWIKS & NIANAL & \\
\hline BP_PYR_R_DII & & GNLVGLNLFL & ALLLSNFGSS & SISAPTADNE & TNKIAEAFNR & ISRFSNWIKS & NIANAL & \\
\hline BP_PYR_S_DII & & GNLVGLNLEL & AIILSNFGSS & SLSAPTADNE & TNKIAEAFNR & ISRFSNWIKS & NIANAI & \\
\hline PNJ_PYR_R_DII & & GNLVVLNLEL & ALLLSNFGSS & SLSAPTADNE & TNKIAEAFNR & ISRFSNKIKS & NIANAI & \\
\hline FIT_PYR_R_DII & & GNLVVLNLEL & ALLISNFGSS & SLSAPTADNE & TNKIAEAFNR & ISRFSNWIKS & NIANAL & \\
\hline FLT_PYR_S_DII & & $\begin{array}{l}\text { GNLVVLNLEL } \\
\ldots \ldots, \ldots \ldots \ldots\end{array}$ & $\begin{array}{l}\text { ALLLSNFGSS } \\
\ldots \ldots \ldots \ldots \ldots\end{array}$ & $\begin{array}{l}\text { SLSAPTADNE } \\
\ldots \ldots \ldots \ldots\end{array}$ & $\begin{array}{l}\text { TNKIAEAFNR } \\
\ldots \ldots \ldots \ldots \ldots\end{array}$ & ISRFSNWIKS & $\begin{array}{l}\text { NIANAL } \\
\ldots \ldots\end{array}$ & \\
\hline
\end{tabular}

\section{Figure 2}

Alignment of the amino acid sequences for the partially amplified domain II, segment 6 of the voltage gated sodium channel gene in the susceptible Musca domestica (GenBank accession number U38813.1) and Aedes aegypti from China (GenBank accession number AY663385.1) compared to the permethrinresistant and permethrin-susceptible strains from six localities in Malaysia. The highlighted letters show the positions of mutation S989P, A1007G and V1016G. Letter ' $R$ ' and ' $S$ ' in the sample name represents resistant and susceptible phenotypes respectively. Asterisk (*) represents identical amino acid. Letters highlighted with grey are the conservative substitution.

\begin{tabular}{|c|c|c|c|c|c|c|c|}
\hline Mugea domegtion & PAREACR BEN & YTWENBAENF & DHWONAYICL & FOVATFROWI & 1500 & & \\
\hline Aedes aegypti susceptible & PDVNACVAEN & YTWENSFMENF & DHVGRAYLCL & FOVATFTGWI & 40 & & \\
\hline AS_PYR_R_DIII & DEVARCVAEN & YTXENGDSEF & DHWOKAYLCL & POVATFRowI & & & \\
\hline AS_PYR_3_DITI & PDVEACVAEN & YTKENSPEST & D\&VGRAYLCL & rOVATTKOWI & & & \\
\hline TDM_PYR_R__DIII & PDVNACVAEN & YTXENSPENF & DHVGKAYLCL & FOVATFRGWI & & & \\
\hline RDM_PYR_a_DIII & PDVNACVAEN & YTKENAPMENF & DUVGRAYLCL & FOVATFTGWI & & & \\
\hline 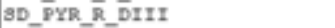 & PDVARCVAEN & YTWENBRENF & DHWORAYZCL & FOVATFKGWI & & & \\
\hline 90_PYR_3_DITI & PDVRACVAEN & 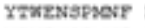 & DAVGRAYLCL & rovazrTGKI & & & \\
\hline BP_PYR_R_DIII & PDVNACVAEN & YTKENSPANF & DAVGRAYLCL & POVATFRGWI & & & \\
\hline QP_PYR_B_DIII & PDVAACVAEN & YTWENBDSENF & DHWOKAYLCL & FOVATFROWI & & & \\
\hline PNJ̄_PYR__̄_DIII & PDVNACVAEN & YTWENSPMENF & DHVGRAYLCL & FOVATFRGWI & & & \\
\hline FLI_PYR_R_DIII & $\begin{array}{l}\text { PEVARACVAEN } \\
\text {... }\end{array}$ & 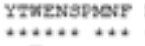 & $\begin{array}{l}\text { DHWGRAYLEL } \\
\text {.... } \ldots \text {.... }\end{array}$ & $\begin{array}{l}\text { POVATFRGWI } \\
\text { A.A. }\end{array}$ & & & \\
\hline Mugor domegtion & OMENDAIDSR & EVD̈ROPIRET & NIMCYLYFVF & FIIFGSFFTL & NLFIOVIIDN & FNEORRRAGG & 1560 \\
\hline Aedes aegypti susceptible & OMENDAIDSR & EVGKOPIRET & NIMAYLYFVF & FIIFGSFTTL & NLFIGVIIDN & FNEOKKKAGG & 100 \\
\hline AB_PYR_R_DIII & QTENDAIDSR & EVGKOPIRET & NIDCYLYFVF & FIICasFFTL & NLFIOVIIDN & FNEQRKKAOS & \\
\hline AS_PYR_S_DIII & OTASDAIDSR & EVGROPIRXT & NT2aCYLYTVY & PIIFGSTrTL & NLPIGVIIDN & nNEORRKaGG & \\
\hline 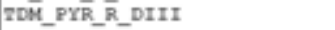 & OMENDAIDGR & EVGROPIRET & NIMYYLYFVF & FIICGSFFTL & NLFIGVIIDN & FNEORKRAGG & \\
\hline 2DM_PYR_B_DII & gmerdardeg & EVGKODIRET & NIMCYLYFVF & PIIPGSFFT & NLPIOVIIDE & FNEORKRACG & \\
\hline SD_PYR_̄̄_DIII & QTENDAIDSR & EVGKQPIRET & NIMCYLYFVF & FIICGSFFTL & NLFIGVIIDN & FNEQRKKAAG & \\
\hline SD_PYR_-3_DITI & onerdardse & EVGTOPIAET & NIDCYLYFVF & PIICG9FrTL & SLPIGVIIDN & nEEORKRaAG & \\
\hline DP_PYR_R_DIII & OMENDATDSR & EVGROPIRET & NIMCYZYFVF & FIIFGSFTTL & NLFIGVIIDN & FNEORKRAGG & \\
\hline BP_PYR_B_DIII & QMENDAIDBR & EVGKQPIRET & NIMCYLYFVF & FIICOSFFTL & SLFIGVIIDN & FNEQRKRAOS & \\
\hline 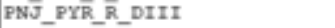 & OMENDAIDAR & EVGROPIRET & NIMCYLYFVF & FIICGSFFTL & NLFIGVIIDN & FNEORKRAGG & \\
\hline FLE_DYR_R_DIII & Qmerdardsa & EVGROPIPEF & NIDCYYYFV & FIrcaspriz & NEFIGVIIDA & FNEORKRTAC & \\
\hline & 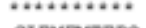 & 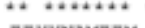 & 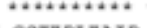 & 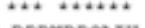 & tantatatat & 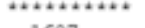 & \\
\hline Musea domestioa & SIEATERDO & 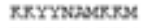 & GgXKRLRAIP & RPRKRPCATV & 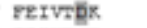 & 1607 & \\
\hline Aedes aegypti susceptible & SLEMFTEDO & RKYYYNDMKKR & GSKKPLKAIP & RPRWRPCAIV & FEIVTNR & 154 & \\
\hline AB_PYR_3_DIII & SIEARTEDO & RKYYYNASAKRA & GSKKPLRAIP & RPRERPCATV & FEIVTNR & & \\
\hline 25M_PYR_B_ptII & 312xenctedo & RK.Yrotiock:Rs & G9RKRLRAIP & RPRWRPCATV & FEIVRNK & & \\
\hline BP_PYR_R_EIII & SIEMFTEDO & RKYYNDAMRKM & GSKKPLRAIP & RPRWRPOAIV & FEIVTNK & & \\
\hline A2_PYR_R_DITI & รLEMrNTEDO & RKXYXosockrs & GIXKRLIRAIP & RPRWRPCAIV & reIVTNK & & \\
\hline IDM_PYR_R_DIII & SLEMFTEDO & RKYYYNAMARRM & GSKKPLKAIP & RPRWRPOAIV & FEIVINR & & \\
\hline 9D_DYR_R_DIII & SIEATCIEDO & RKYYYATEAKR: & G9KR.DLRAIP & RERKRDOATV & FEIVINR & & \\
\hline 3D_PYR_3_DITI & sLEMratred & RKYXXNasorRs & GSKKPLKAIP & RPRWRPCAIV & FEIVTNK & & \\
\hline 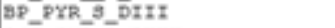 & SIENTKREDO & rK.Yrstosor.ros & G9KKRLRAIP & RPRKRPOAIV & reIvTNK & & \\
\hline PNJ̃_PYR_R_DIII & SLEMFTEDO & RKYYNADMRRM & GSKKPLRAIP & RPRWRPCAIV & FEIVTNR & & \\
\hline FIS_PYR_R_DIII & SLEARTEDQ & RKYYNRACKKA & GgKKDLRAID & RPRERPCAIV & FEIVTNK & & \\
\hline & 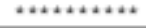 & tatcktatet & atentatet & ntatatate & ntat. & & \\
\hline
\end{tabular}




\section{Figure 3}

Amino acid alignment sequences of the partially amplified domain III, segment 6 of the voltage gated sodium channel gene in the susceptible Musca domestica (GenBank accession number U38813.1) and Aedes aegypti (GenBank accession number MF794972.1) compared to the permethrin-resistant and permethrin-susceptible strains from six localities in Malaysia. Letter ' $R$ ' and ' $S$ ' represents resistant and susceptible phenotype respectively. The highlighted letter shows the position of F1534C in domain III segment 6 . Asterisks ${ }^{*}$ ) represent identical amino acid. Letters highlighted with grey are the conservative substitution.
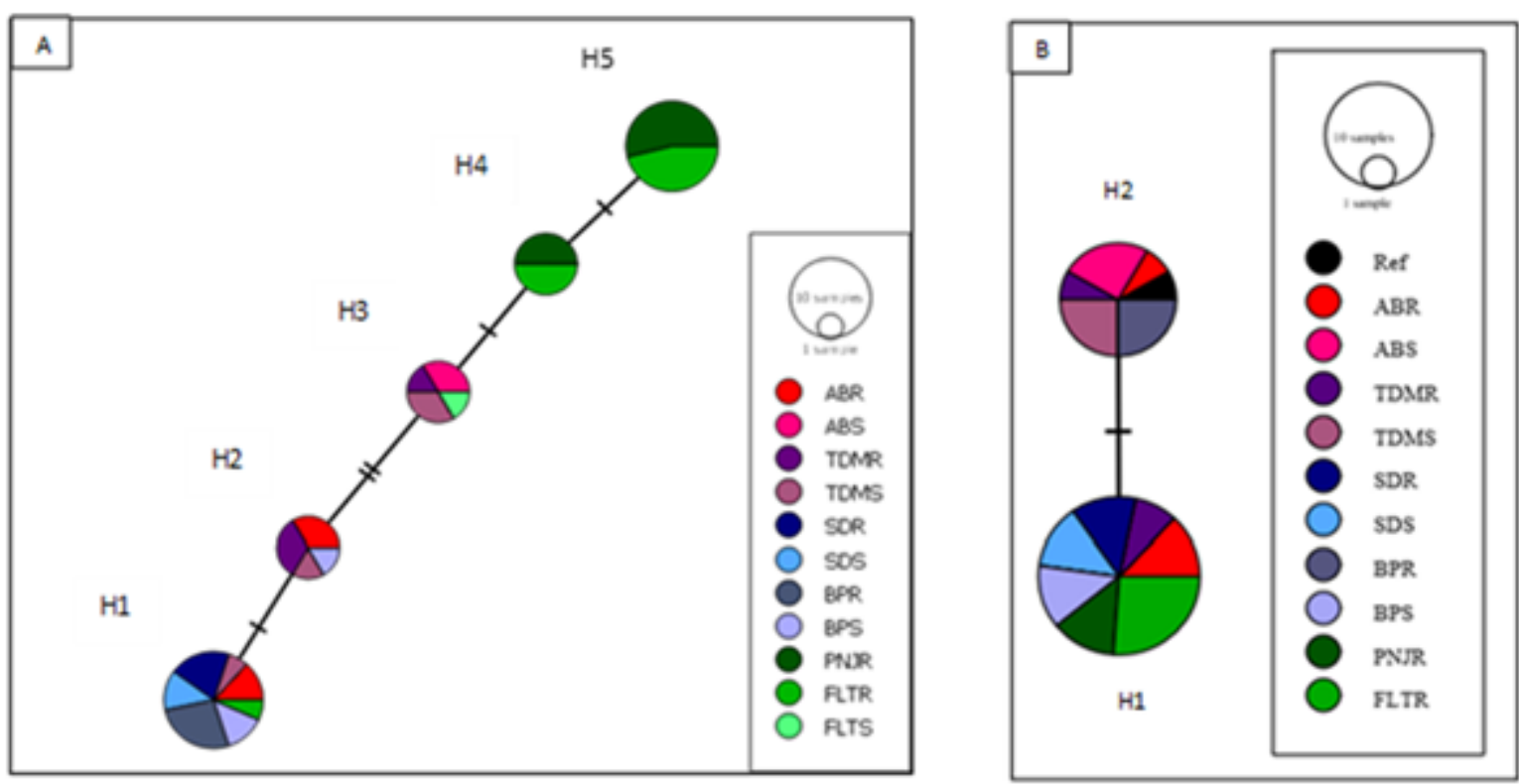

\section{Figure 4}

TCS network for the vgsc haplotype of fragment domain II (A) and III (B) between permethrin-resistant and permethrin susceptible samples in all six population of Ae. aegypti in Malaysia. ABR, Alam Budiman resistant; ABS, Alam Budiman susceptible; TDMR, TUDM, Subang resistant; TDMS, TUDM, Subang susceptible; SDR, Sungai Dua resistant; SDS, Sungai Dua susceptible; BPR, Balik Pulau resistant; BPS, Balik Pulau susceptible; PNJR, Pauh, Panji resistant; FLTR, Flat Buluh Kubu resistant; FLTS, Flat Buluh Kubu susceptible

\section{Supplementary Files}

This is a list of supplementary files associated with this preprint. Click to download.

- Graphicalabstractimage.docx

- AdditionalfileFigS1Image.docx

- AdditionalfileFigS2Image.docx 
- AdditionalfileTableS1Image.docx

- AdditionalfileTables2.docx

- AdditionalfileTableS3Image.docx 